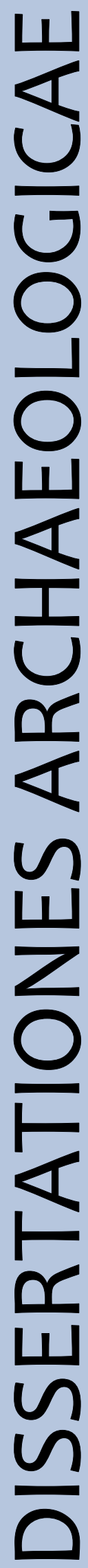

ex Instituto Archaeologico Universitatis de Rolando Eötvös nominatae
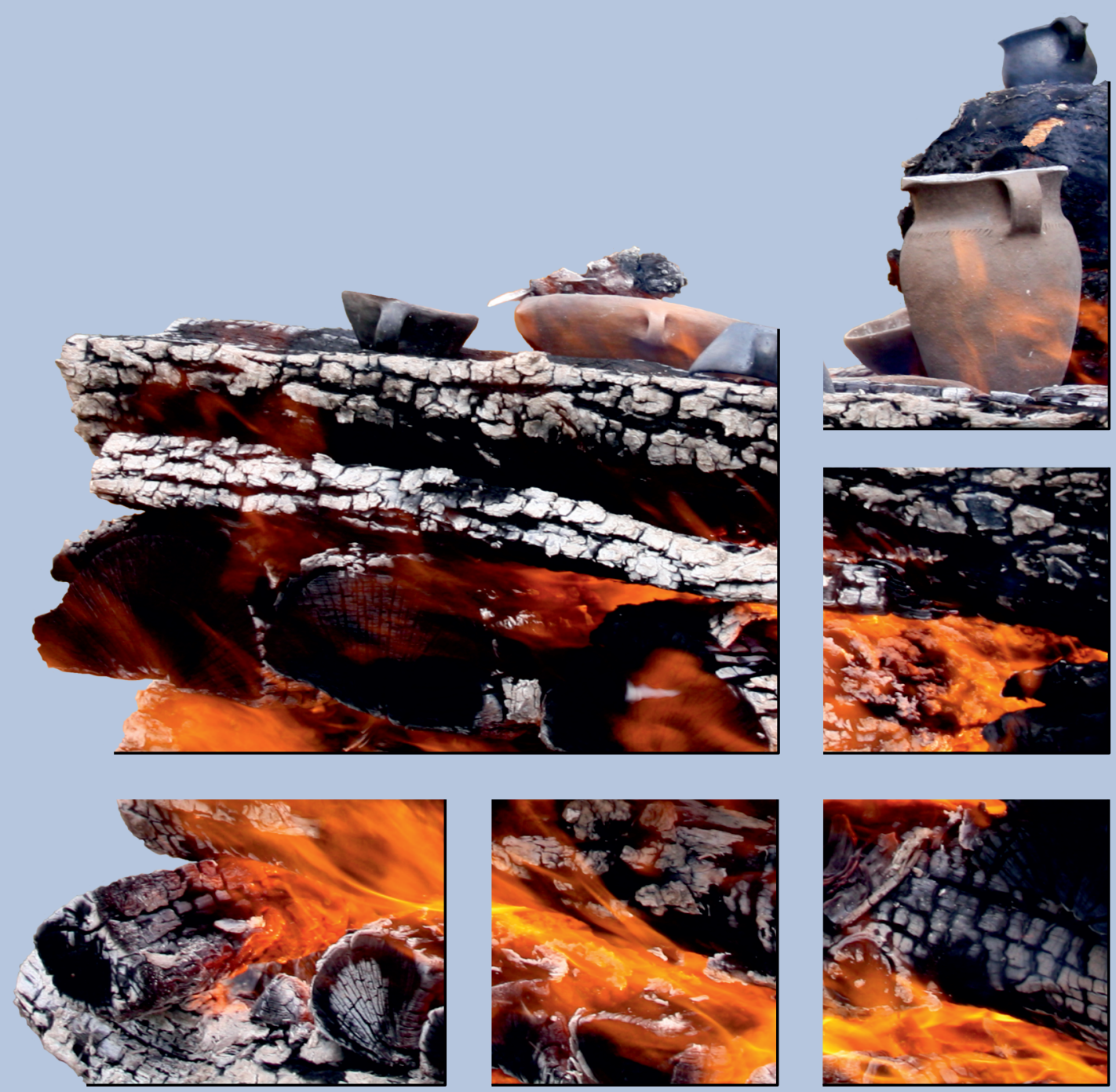

$$
\text { Ser。 3. No } 0_{0} \sigma_{0} \mid 2018
$$




\section{Dissertationes Archaeologicae ex Instituto Archaeologico}

Universitatis de Rolando Eötvös nominatae Ser. 3. No. 6.

Budapest 2018 


\section{Dissertationes Archaeologicae ex Instituto Archaeologico}

Universitatis de Rolando Eötvös nominatae Ser. 3. No. 6.

Editor-in-chief:

DÁvid BARTUS

Editorial board:

LÁsZló BARTOSIEWICZ

LÁSZLÓ BORHY

ZOLTÁN CZAJLIK

ISTVÁN FELD

GÁBOR KALLA

PÁL RACZKY

MiKLÓS SZABÓ

Tivadar Vida

Technical editor:

GÁBOR VÁcZI

Proofreading:

ZsófIA KondÉ

SzILVIA BARTUS-SzÖLLősI

Aviable online at http://dissarch.elte.hu

Contact: dissarch@btk.elte.hu

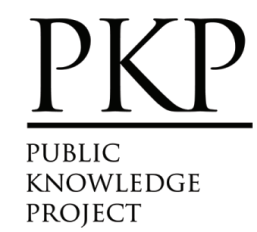

๑ E Eötvös Loránd University, Institute of Archaeological Sciences

Layout and cover design: Gábor Váczi

Budapest 2018 


\section{CONTENTS}

Zsolt Mester

In memoriam facques Tixier (1925-2018)

\section{ARTICLES}

Katalin SEBőK

On the possibilities of interpreting Neolithic pottery - Az újkökori kerámia értelmezési lehetőségeiről

András FüZESI - Pál RACZKY

Öcsöd-Kováshalom. Potscape of a Late Neolithic site in the Tisza region

Katalin SEBőK - Norbert FARAgó

Theory into practice: basic connections and stylistic affiliations of the Late Neolithic settlement at Pusztataskony-Ledence 1

Eszter Solnay

Early Copper Age Graves from Polgár-Nagy-Kasziba

László GuCsi - Nóra Szabó

Examination and possible interpretations of a Middle Bronze Age structured deposition

Kristóf FÜLÖP

Why is it so rare and random to find pyre sites? Two cremation experiments to understand the characteristics of pyre sites and their investigational possibilities

Gábor János TARBAY

"Looted Warriors" from Eastern Europe

Péter MogYoRós

Pre-Scythian burial in Tiszakürt

Szilvia JoHÁczi

A New Method in the Attribution? Attempts of the Employment of Geometric Morphometrics in the Attribution of Late Archaic Attic Lekythoi 
The Roman aqueduct of Brigetio

Lajos JuHÁsz

A republican plated denarius from Aquincum

Barbara HAJDU

Terra sigillata from the territory of the civil town of Brigetio

Krisztina HoppÁL - István VIDA - Shinatria AdHityatAma - Lu Yahui 461

'All that glitters is not Roman'. Roman coins discovered in East Java, Indonesia.

A study on new data with an overview on other coins discovered beyond India

\section{FIELD REPORTS}

Zsolt MESTER - Ferenc CSERPÁK - Norbert FARAGÓ

Preliminary report on the excavation at Andornaktálya-Marinka in 2018

Kristóf FÜLÖP - Denisa M. LÖNHARDT - Nóra SZABÓ - Gábor VÁcZI

Preliminary report on the excavation of the site Tiszakürt-Zsilke-tanya

Bence Simon - Szilvia JohÁcZI - Zita KIS

Short report on a rescue excavation of a prehistoric and Árpádian Age site near Tura

(Pest County, Hungary)

Zoltán CzAJlik - Katalin NovinszKi-Groma - László RupNIK - András BöDőcs - et al. 527

Archaeological investigations on the Süttö plateau in 2018

Dávid BARTus - László BORHY - Szilvia JoHÁczi - Emese SzÁMADó

Short report on the excavations in the legionary fortress of Brigetio (2017-2018)

Bence Simon - Szilvia JoháczI

Short report on the rescue excavations in the Roman Age Barbaricum near Abony

(Pest County, Hungary)

Szabolcs Balázs NAGY

Recent excavations at the medieval castle of Bánd 


\section{Thesis Abstracts}

Rita JENEY

Lost Collection from a Lost River: Interpreting Sir Aurel Stein's "Sarasvatī Tour" in the History of South Asian Archaeology

István VIDA

The Chronology of the Marcomannic-Sarmatian wars. The Danubian wars of Marcus Aurelius in the light of numismatics

Zsófia MASEK

Settlement History of the Middle Tisza Region in the $4^{\text {th }}-6^{\text {th }}$ centuries AD.

According to the Evaluation of the Material from Rákóczifalva-Bagi-földek 5-8-8A sites

Alpár Doвоs

Transformations of the human communities in the eastern part of the Carpathian Basin between the middle of the $5^{\text {th }}$ and $7^{\text {th }}$ century. Row-grave cemeteries in Transylvania, Partium and Banat 


\title{
The Roman aqueduct of Brigetio
}

\author{
Anita Benes \\ Institute of Archaeological Sciences \\ Eötvös Loránd University \\ benesanita@centrum.sk
}

\begin{abstract}
The aim of the present study is to examine the literary sources and the archaeological material regarding the aqueduct of Brigetio. Based on the available information the paper examines the problem of the localization of the source which supplied the aqueduct. The catalogue includes the descriptions of the lead and terracotta water pipes from Brigetio now in the Roman collection of the Hungarian National Museum. The results are presented with regards to the construction of the urban water distribution system.
\end{abstract}

The Roman aqueduct of Brigetio is first mentioned by Luigi Ferdinando Marsigli. In his work written in 1726 he describes an aqueduct made of brick and located in the marsh (in palude). He displays the route of the aqueduct on a map, according to which it ran between Brigetio and Tata (Fig. 1). ${ }^{1}$

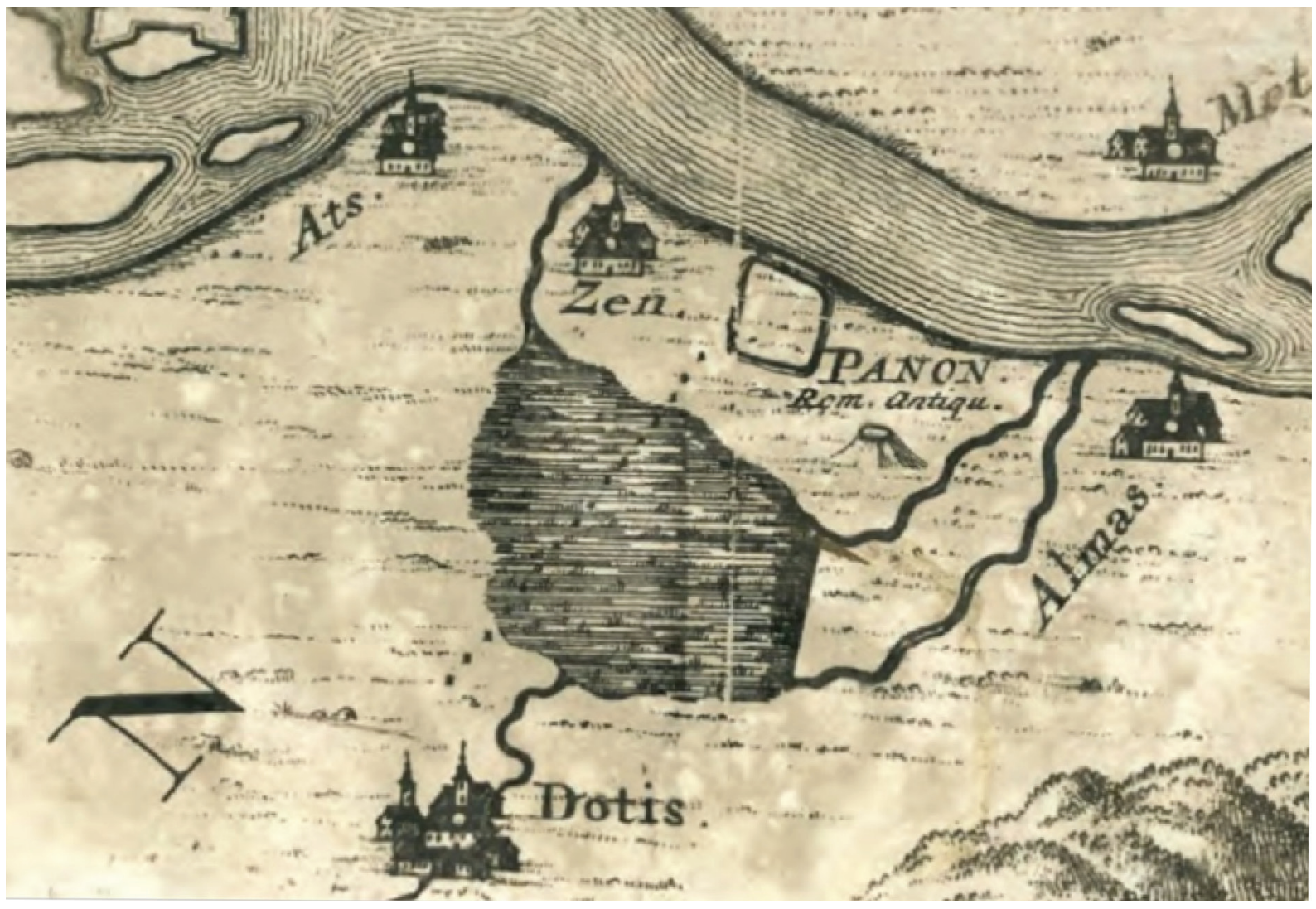

Fig. 1. Map of Luigi Ferdinando Marsigli (Marsigli 1726, 3).

1 Marsigli 1726, 3.

DissArCH Ser. 3. No. 6. (2018) 419-440.

DOI: 10.17204/dissarch.2018.419 
The next description of the aqueduct dates to 1735. Mátyás Bél mentions the aqueduct between Brigetio and Tata numerous times in his book regarding Komárom county. At that time, the ruins of the aqueduct were still visible on the bank of the Danube near Szonny, heading towards Tata through Naszály. Parts of the construction were underground, however near the surface, while other parts on arcades. Bél also stated that it was partly built of tuff stuck by lime. ${ }^{2}$ In his description of Tata he refers to the aqueduct in context of presenting the building activity of King Matthias Corvinus in this town, and attributes the construction of the aqueduct to the king. However, when ${ }^{3}$ describing the ruins of Brigetio, Bél mentions the aqueduct again and suggests that it may be dated to the Roman times. ${ }^{4}$ In his description about Naszály he mentions that the aqueduct runs through the village and whole vaults can still be dug up in some places. ${ }^{5}$ The next source regarding the Roman aqueduct of Brigetio, the report of Sándor Mikoviny for the Hungarian Royal Chamber, dates to $16^{\text {th }}$ December 1747. During his draining work Mikoviny recorded important information about the Roman buildings of the region. In his report he lists the Roman memories of Szonny and also mentions the Roman aqueduct which, according to his description, consists of an underground vaulted channel and arcades. The aqueduct is two German miles long $(15.2 \mathrm{~km})$ and brings the spring-waters from Tata to Brigetio. ${ }^{6}$ Mikoviny marked the route of the aqueduct on his map between Tata and Brigetio (Fig. 2). ${ }^{7}$ During the 1880s Rudolf Gyulai studied the route of the aqueduct. In his letter written in 1885 he claims that the purpose of the aqueduct was to supply the military baths of Brigetio as well as to provide fresh drinking water for the city, but primarily it served the mills. He mentions lead and terracotta water pipes which were found in Brigetio and also a carved limestone fountain found in 1873 in the vineyards on the bank of the Danube near Szőny. According to Gyulai's description, in the 1880s the route of the aqueduct was still visible and could be followed for as long as $6.25 \mathrm{~km}$ from the legionary camp in Szőny up to Naszály. He recounts the 'Legend of the golden duck' about King Matthias Corvinus putting a gilded wooden duck into the channel of the aqueduct at its source in Tata, which then swam down the channel and popped up in the legionary camp in Brigetio. Regarding the source of the aqueduct Gyulai mentions that according to the contemporary views the main source of the aqueduct can be found in Tata in the garden of the Eszterházy hospital. He also refers to Ede Risz who claimed that the aqueduct was supplied by the water collected by a nearby Roman dam. According to Risz, the water collected by the dam was led into the channel of the aqueduct in Naszály, where in the 1850s complete sections of the underground channel were found. Unfortunately, in 1885 all that Rudolf Gyulai could find were ruins as a result of the intense reuse of the building material of the aqueduct by the locals. He could follow the route of the aqueduct through Naszály along the main road from Tata to Naszály. From Naszály, he could trace the route of the aqueduct by the line of debris and holes dug by the locals to aquire the stone material. In the sides of low hills the ruins were still visible but in the fields the traces of the aqueduct totally vanished. Gyulai found whole sections of the aqueduct channel running in a ramp near Almás and Billegpuszta. Near Bélapuszta the aqueduct turned right but only its ruins remained. According to the description of Rudolf Gyulai, in sections where the

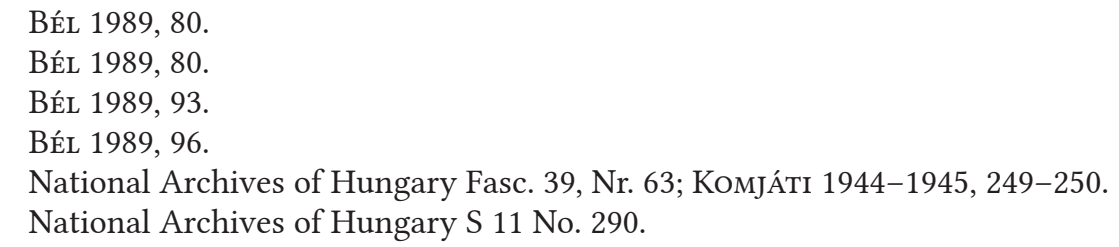


aqueduct channel remained intact, it was $1 \mathrm{~m}$ high and $0.8 \mathrm{~m}$ wide. The aqueduct entered the legionary camp approximately in the middle of the western side of the camp and joined to a $19 \mathrm{~m}$ long and $7.6 \mathrm{~m}$ wide building, probably the reservoir, the so-called castellum. At this location workmen found about 200 kilograms of lead, probably the lead water pipes of the water distribution system, as well as inscribed stones. The pillars of the arcades were not visible and could not be found anymore in the 1860's. According to Rudolf Gyulai, the aqueduct was divided into two channels at Béla-major, one of the branches ran westwards to the lowerlying city while the other branch built on arcades supplied the higher-lying legionary camp. ${ }^{8}$

In his second letter regarding the aqueduct of Brigetio written in 1886, Rudolf Gyulai discusses the possible sources of the aqueduct. He refuses to accept above-mentioned opinion of Ede Risz about the aqueduct being supplied by the water collected by a Roman dam. Instead, Gyulai accepts the explanation of Milos Berkovics-Borota who claims that it would have been impossible to raise the level of the water collected by the dam to the appropriate height to supply the aqueduct. Based on this, Gyulai Berkovics-Borota claims the source of the aqueduct must be located in Tata. According to him, as the springs situated in the garden of the Eszterházy hospital and the springs of Kertalja are not abundant enough, the Romans might have used the water of the Old Lake

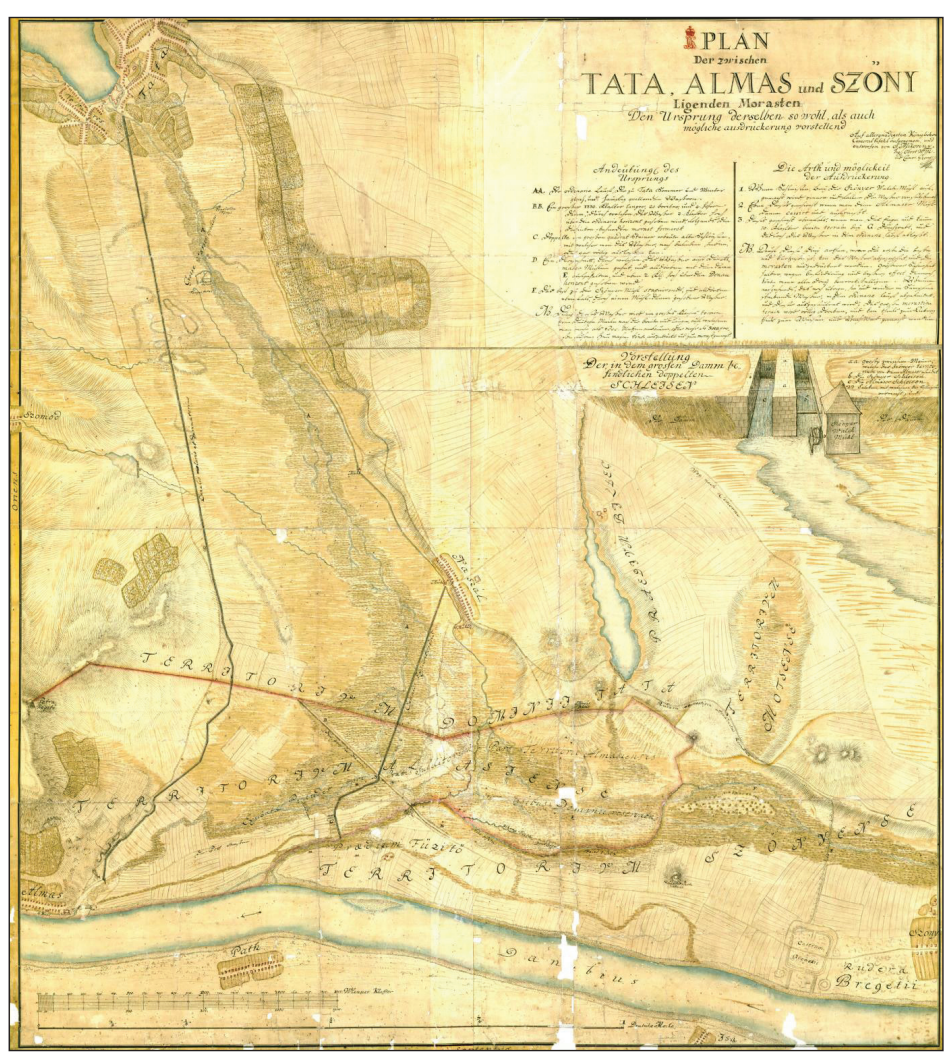

Fig. 2. Map of Sámuel Mikoviny (National Archives of Hungary S. 11 No. 290).

in Tata. He mentions that in the Kertalja street a section of the underground aqueduct channel was found during digging a well. The aqueduct channel left the city of Tata along Kertalja street and reached Brigetio through the vineyards of Tata and Naszály. Gyulai and Berkovics-Borota also gives an addition to the 'Legend of the golden duck' according to which the 'golden duck' swam attached to a wire and carried letters from Tata to Szonny. ${ }^{9}$ Thanks to the letters of Rudolf Gyulai we have a detailed description about the condition of the aqueduct in the 1880's. Based on his reports some sections of the aqueduct were well preserved. The construction consisted of underground sections which ran close to the surface, partly in a ramp, as well as of aqueduct channels built on arcades in the vicinity of the legionary camp, though the pillars of the arcades were not visible already in the 1860's. To his second letter, Gyulai attached a map of the route of the aqueduct (Fig. 3).

9 Gyulai 1886. 


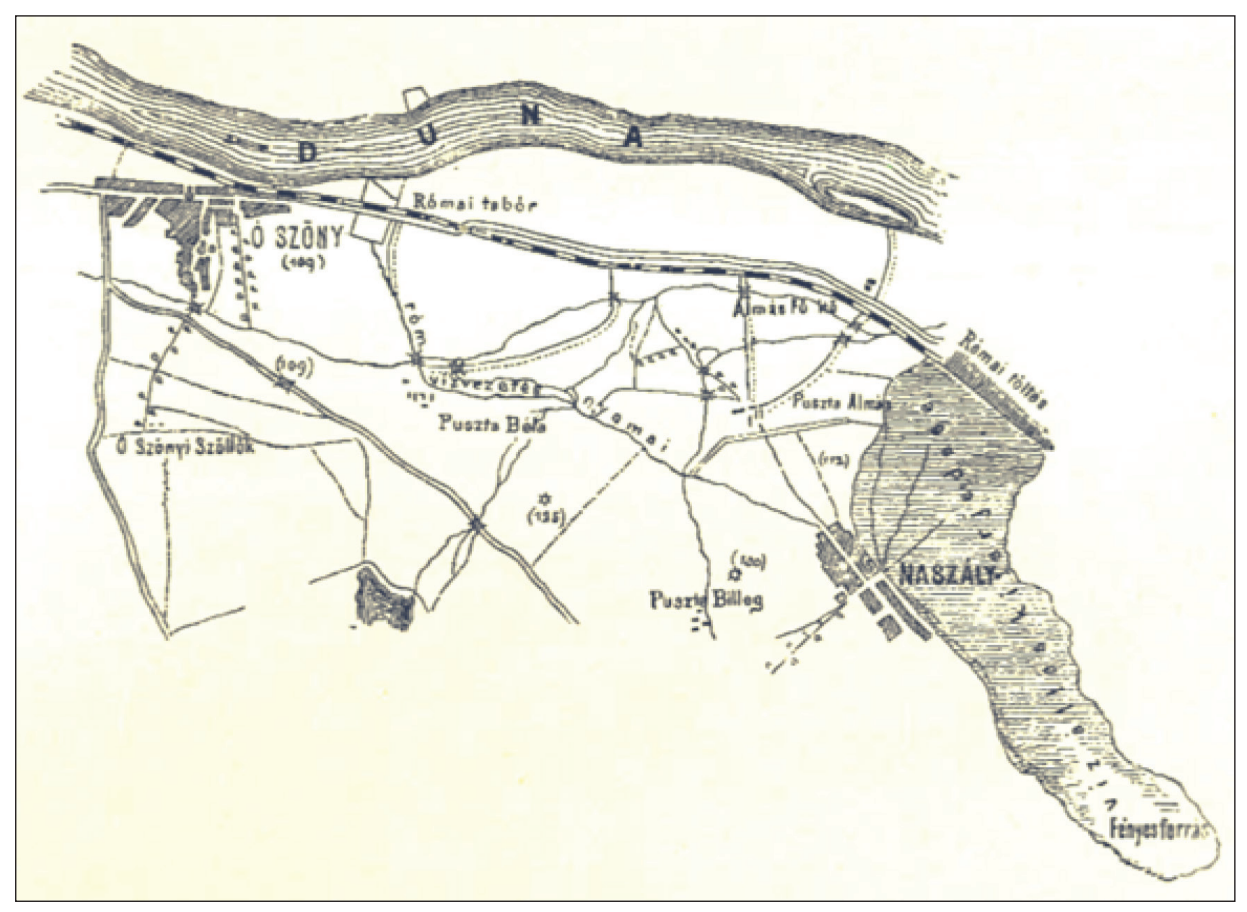

Fig. 3. Map of Rudolf Gyulai (GyulaI 1886, 333).

During the building of the modern fort located in the southeastern corner of the Roman legionary camp, Milos Berkovics-Borota, engineering faculty captain observed the Roman buildings and published the plan of the military camp and a map showing the route of the aqueduct. On his map the route of the aqueduct starts in Tata, from where it runs through Naszály heading to Bélapuszta where it turns north towards the legionary camp of Brigetio (Fig. 4). ${ }^{10}$

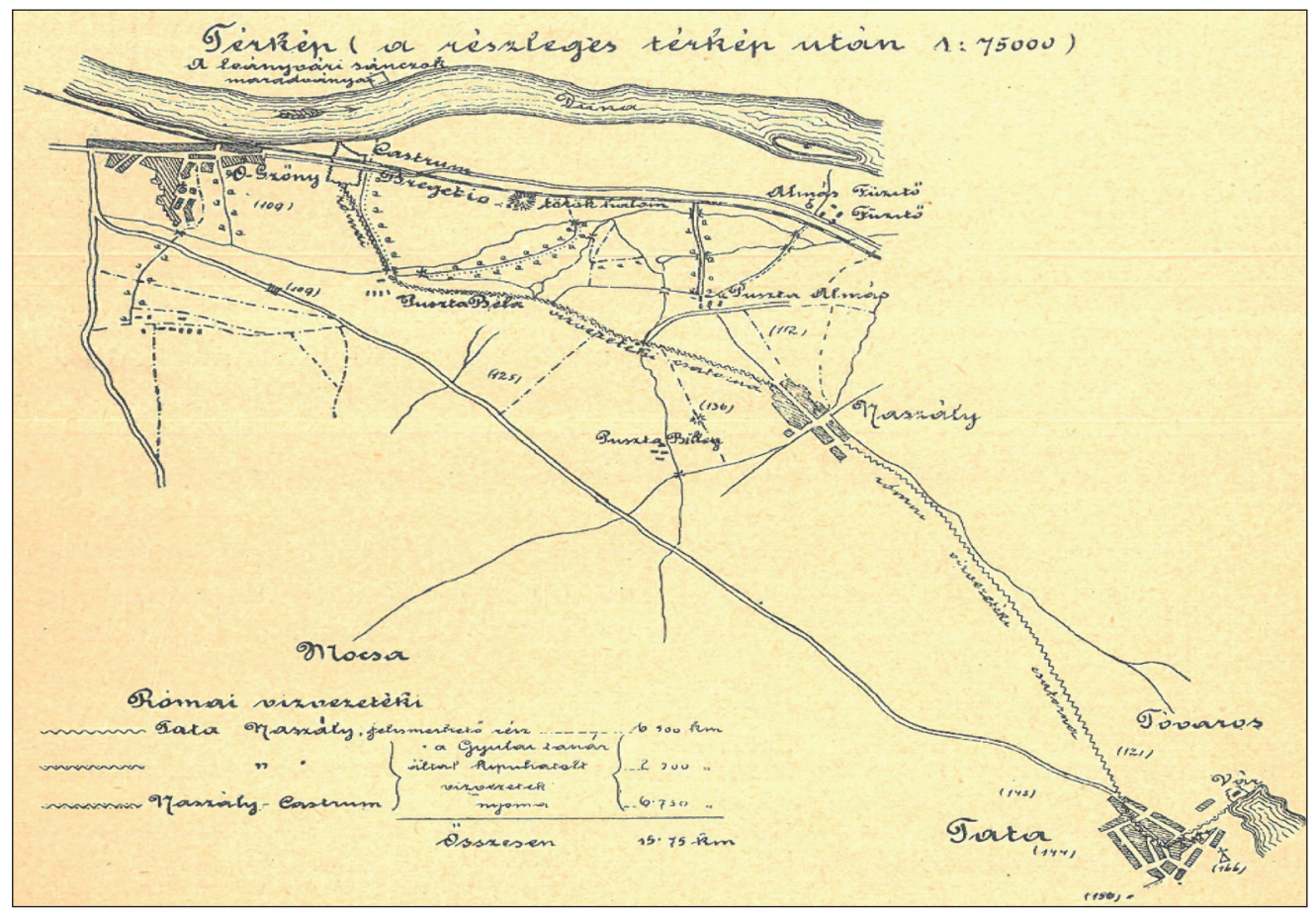

Fig. 4. Map of Milos Berkovics-Borota (Berkovics-Borota 1886, 393).

10 Berkovics-Borota 1886, 393. 


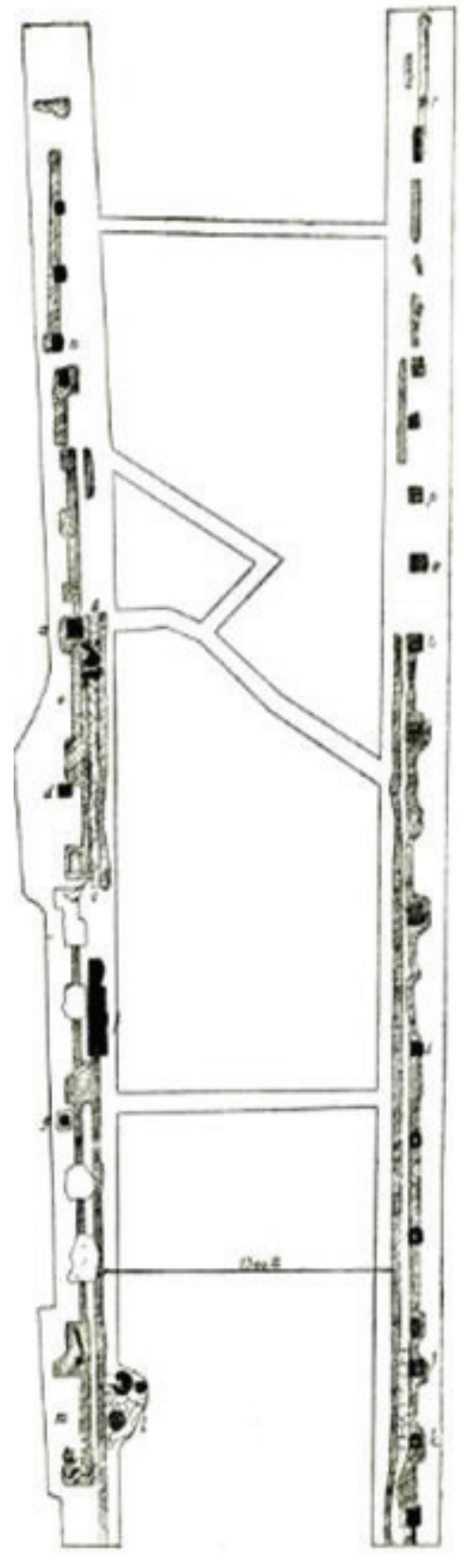

Fig. 5. The road and the supposed aqueduct channels excavated by István Paulovics (Paulovics 1941, Abb. 2).
The first excavations regarding the aqueduct were carried out in 1927 led by István Paulovics. During the excavations the Roman road leading to Bélapuszta came to light. About $240 \mathrm{~m}$ from the south gate of the military camp, along the 10.5-12 m wide road ran the supposed aqueduct which was also partly excavated. Its channel was 37-46 cm wide and 30-40 cm deep. The interior of the channel was coated with terrazzo and its outer wall was supported by pillars about $2-3$ $\mathrm{m}$ apart from each other. The channels which came to light on both sides along the road were similar, only some difference in quality and elaboration could be documented between them (Fig. 5). According to István Paulovics the channels were aqueduct channels, the more elaborated channel coated with terrazzo supplying the city with drinking water, while the other had industrial purposes and supplied the local mills. He surveyed the visible ruins of the supposed aqueduct and published a map about its route (Fig. 6). According to him, the excavated channels are to be identified with the aqueduct described by Luigi Ferdinando Marsigli. He assumed that the route of the aqueduct was approximately $14 \mathrm{~km}$ long and claimed that the aqueduct was supplied by the Fényes springs located in Tata. ${ }^{11}$

In her book on Roman public works and services on the territory of Hungary, Klára Póczy shares the above-mentioned opinion of István Paulovics about the different purposes of the more and less elaborated channels, mentioning a parallel from Aquincum. ${ }^{12}$

Póczy also summarizes all information available in her time about the aqueduct of Brigetio, besides which she mentions an inscribed lead pipe found in Brigetio which was owned by Kálmán Darnay in 1890. This inscribed lead pipe will be further discussed below. ${ }^{13}$

In my opinion the channels excavated by István Paulovics in 1927 cannot be identified as aqueduct channels. I believe, that based on their structure and size it is more possible to identify them as water drainage channels along both sides of the road, which were common in Roman times. Among others, we can find them in Aquincum. ${ }^{14}$

11 Paulovics 1941, 145-151.

12 Póczy 1980, 66.

13 Darnay 1897; Póczy 1980, 54-55, 63-64, 66, 78.

14 Póczy 1980, 80, Fig. 72. 


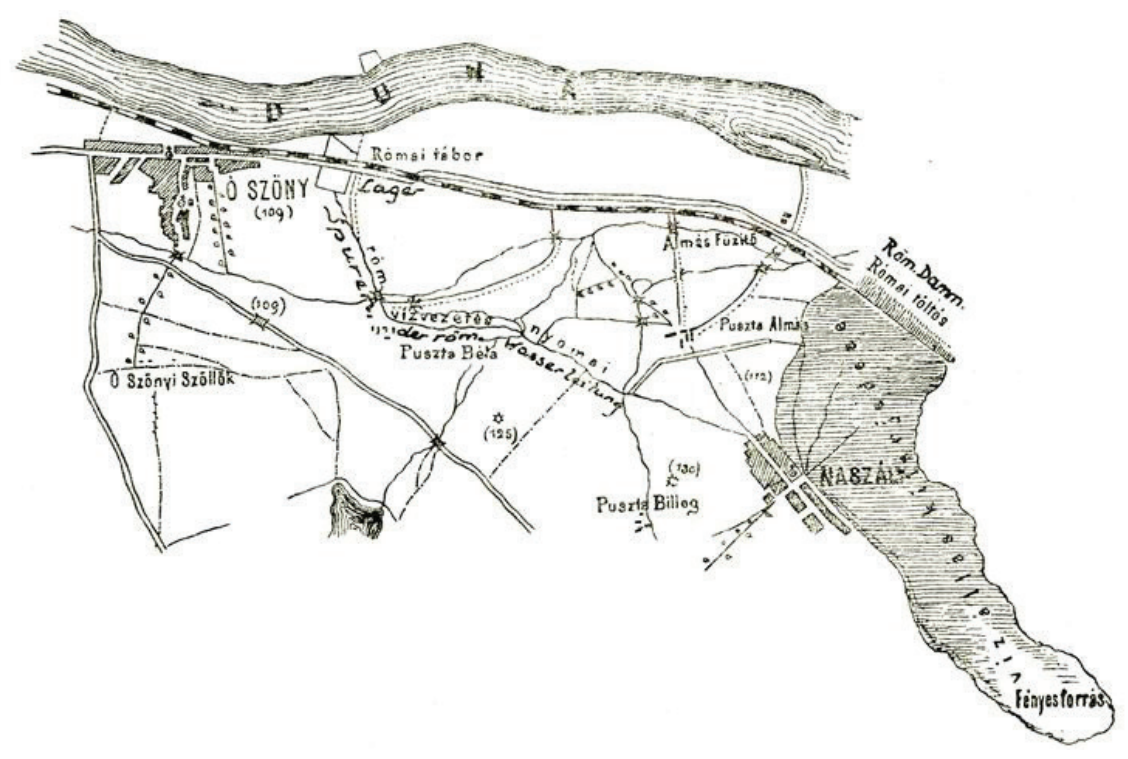

Fig. 6. Map of István Paulovics (Paulovics 1941, Abb. 3).

After the excavations led by István Paulovics, not much attention was turned to the aqueduct of Brigetio. In his study about the topography of Brigetio, László Barkóczi mentions the aqueduct and gives a summary of the information currently available on it. ${ }^{15}$ Nowadays, thanks to recent geomorphological and hydrological studies, attention is turned again to the aqueduct of Brigetio. In their study regarding the source of the aqueduct of Brigetio, István Viczián and Friderika Horváth claim that the springs of the Old Lake in Tata supplied the aqueduct. According to them, the water was collected by the Romans in the Old Lake of Tata, meaning that the lake has Roman origins. ${ }^{16}$

László Rupnik and Bence Simon studied the geography and relief of the region and presented the optimal route of the aqueduct compared with the routes mapped by Sámuel Mikoviny and Rudolf Gyulai. Based on the map of Sámuel Mikoviny, Rupnik and Simon assumed that the source of the aqueduct was the spring at Kőkút köz no. 1 in Tata, which lies $136 \mathrm{~m}$ above sea level, because here the aqueduct could collect the water of the most dense group of springs. As the end of the route of the aqueduct they chose the area close to the south gate of the legionary camp which lies $107 \mathrm{~m}$ above sea level. This way, the optional route and the routes mapped by Sámuel Mikovinyi and Rudolf Gyulai cross each other several times and run close to each other, indicating quite a narrow zone, the intense study of which is suggested in the future. In July of 2018 I had the opportunity to join Bence Simon in the survey of the optimal route of the aqueduct. During the survey we found vaulted parts of walls coated with terrazzo and some ceramics.

According to the DDM 10 model created by above-mentioned authors, the route of the aqueduct is $15.2 \mathrm{~km}$ long, the difference between the levels of the starting and ending points (in other words, the fall) is $29 \mathrm{~m}$, therefore the slope is $1.9 \%{ }^{17}$ which differs from the slope of $5 \%$ o

17 Hereby I would like to thank Bence Simon and László Rupnik for sharing their results regarding the aqueduct of Brigetio. 
suggested by Vitruvius ${ }^{18}$ as well as that suggested by Plinius, which is $0,2 \% .{ }^{19}$ In my opinion, due to the low discharge of the spring of Kökút köz, It is unlikely that the Romans chose this spring to supply the aqueduct, especially because there are many abundant springs nearby, such as the Fényes springs or the Great spring under the Castle. The question of the source of the aqueduct will be further discussed below.

In summary, we can state that the aqueduct of Brigetio ran between Tata and the legionary camp of Brigetio and supplied the castellum divisiorum, standing at the western corner of the camp, with fresh water. From the castellum divisiorum the water was distributed to several buildings by lead and terracotta water pipes. When building an aqueduct the Romans applied different architectural solutions. For example, certain sections of the aqueduct channel running on lower lying terrain were placed on arcades. Elsewhere the channel ran following the terrain in a masonry aqueduct channel, a so called surface channel near the ground level built by 'cut and cover' technique. ${ }^{20}$ The surface channel, according to the sources mentioned above, was vaulted and covered with terrazzo.

\section{The source of the aqueduct of Brigetio}

According to the written sources which mention or describe the aqueduct of Brigetio, its source was beyond question in Tata. On the map of Luigi Ferdinando Marsigli, the earliest map available showing the route of the aqueduct, its starting point and therefore its source was marked in Tata, although the map does not indicate which spring supplied it (Fig. 1). ${ }^{21}$

Mátyás Bél also claims that the aqueduct ran between Brigetio and Tata but does not mention which spring the Romans used to supply Brigetio with fresh water. ${ }^{22}$

The map of Sámuel Mikoviny is more detailed. According to it, the source of the aqueduct can be found near Kőkút köz (Fig. 2). ${ }^{23}$

Rudolf Gyulai, as mentioned above, discusses the possible sources of the aqueduct in two subsequent letters, however, he changes his opinion on this topic in between. In his first letter, relying on contemporary opinions he mentions the spring of the Eszterházy hospital as a possible source. He also refers to Ede Risz, according to whom the aqueduct may have been supplied by the waters collected by a nearby Roman dam, ${ }^{24}$ In his second letter however, Gyulai already refuses Risz's idea and claims that the source of the aqueduct can neither be the spring of the Eszterházy hospital nor those of Kertalja street because of their low discharge. In his opinion, it is more probable that the aqueduct used the water of the Old Lake in Tata, which was supplied by the eponymous stream Tata. ${ }^{25}$

18 Vitruvius: De Arch. 8.6.1.

19 Plinius: Nat. Hist. 31.57.

20 I use the terminology introduced by Trevor A. Hodge (1992, 93-94). According to him, most of the Roman aqueduct channels were surface channels, which did not run deep underground and were not raised high on arcades but followed the natural surface of the land instead. In order to be protected, the surface channels were built usually about $0.5-1 \mathrm{~m}$ below ground level. To build a surface channel the Roman used the so-called 'cut and cover' technique, meaning that they dug a ditch, built the channel inside it and covered it up again.

21 MARSIGLI 1726, 3.

22 BÉL 1989, 80.

23 National Archives of Hungary S. 11 No. 290.

24 Gyulai 1885.

25 Gyulai 1886. 
According to the map of Milos Berkovics-Borota, the source of the aqueduct can be localized at the Old Lake near the Castle of Tata (Fig. 4). ${ }^{26}$ István Paulovics suggests the aqueduct of Brigetio was supplied by the abundant Fényes springs of Tata (Fig. 6). ${ }^{27}$

Lately, István Viczián and Friderika Horváth suggested that the springs of the Old Lake in Tata may be identified as the source of the aqueduct and the Old Lake itself may have Roman origins as well. ${ }^{28}$ Bence Simon and László Rupnik, relying on the map of Sámuel Mikoviny, marked Kökút köz no. 1 as the possible source of the aqueduct, because here the aqueduct could collect the discharge of the most dense group of springs. ${ }^{29}$

Beyond the fact that - supported by all above-mentioned historical sources - the source of the aqueduct of Brigetio was located in Tata, I believe that in order to identify the exact spring, it is important to study the springs of Tata from a hydrological point of view.

On the territory of the town, within an area of approximately $10-15 \mathrm{~km}^{2}$ lying $118-141 \mathrm{~m}$ above sea level, 30-40 springs of higher discharge (from 50-100 l/min up to $81000 \mathrm{l} / \mathrm{min}$ ) can be located (Tab. 1, Fig. 7). Beside these abundant springs numerous springs of lower discharge (1-2 l/min up to 10-20 l/min) can also be found in Tata, however their exact number and location is unknown due to the lack of research. According to surveys carried out at the beginning of the $20^{\text {th }}$ century, the total daily discharge of all the springs of Tata was $156000 \mathrm{l} /$ $\min \left(225000 \mathrm{~m}^{3}\right)$. We also have precise data from the 1950s, however, by this time the mines of Tatabánya alredy had serious negative effects on the discharge of the springs. Nowadays the most accepted estimated daily discharge of all the springs of Tata is $78000 \mathrm{l} / \mathrm{min}{ }^{30}$

According to Henrik Horusitzky, the springs located on the main fault-line had the highest discharge: the Fényes springs ( 81000 l/min)and the springs of the English Park (60000 l/min). ${ }^{31}$ Out of these, the Fényes springs are located on the lowest elevation above sea level. Altogether five springs belong to this group, but only three of them have significant discharge. The average temperature of the water is $22{ }^{\circ} \mathrm{C} .{ }^{32}$

The above-mentioned written sources and studies suggest several possibilities considering the location of the source of the aqueduct of Brigetio: the spring of Kökút köz, the spring of the Eszterházy hospital, the springs in the area of the Old Lake as well as the Fényes springs.

The spring of Kökút köz is located $133.5 \mathrm{~m}$ above sea level. In 1919, its estimated discharge was $32.4 \mathrm{l} / \mathrm{min}$, meaning a daily discharge of $46.656 \mathrm{~m}^{3}$. Supposing the Romans also connected other springs in the vicinity to supply the aqueduct, such as the springs of Komárom street, the discharge could be increased up to $1800 \mathrm{l} / \mathrm{min}$, so we can count with a daily discharge of $2592 \mathrm{~m}^{3}$. If we accept that the aqueduct was supplied by these springs, we can state that the aqueduct was able to provide approximately $2592 \mathrm{~m}^{3}$ of spring water daily.

Regarding the next possibility, the springs of the Eszterházy hospital (recently called the springs of the Castle garden), we can count with a discharge of $60 \mathrm{l} / \mathrm{min}$ according to the 1919

26 Berkovics-Borota 1886, 393.

27 Paulovics 1941, 145-151.

28 ViCZIÁN - HoRVÁTH 2006, 268-269.

29 According to the verbal communication of Bence Simon.

30 BallabÁs 2004, 2-4, Tabs 1-2.

31 HORUSITZKY 1923, 74-75.

32 Fogarasi 2001, 6. 
survey, which means a daily discharge of $86.4 \mathrm{~m}^{3}$. In the case of these springs, the elevation above sea level is $135.3 \mathrm{~m}$.

In case the source of the aqueduct was in the area of the Old Lake, the Great spring under the Castle had a discharge high enough to supply the aqueduct (10998 1/min in 1919, daily discharge: $15837.12 \mathrm{~m}^{3}$ ). Its elevation above sea level is $118 \mathrm{~m}$.

Compared to the above-mentioned springs, the Fényes springs had the highest discharge of all. The springs are located 118-119 m above sea level, in 1919 their discharge was 81000 l/min (daily discharge: $116640 \mathrm{~m}^{3}$ ).

\begin{tabular}{|c|c|c|c|c|}
\hline Name of the spring & $\begin{array}{l}\text { Elevation above } \\
\text { sea level }(m)\end{array}$ & $\begin{array}{c}\text { Discharge estimated by } \\
\text { Henrik Horusitzky } \\
\text { in } 1919(\mathrm{l} / \mathrm{min})\end{array}$ & $\begin{array}{c}\text { Estimated discharge in } \\
1950(\mathrm{l} / \mathrm{min})\end{array}$ & Temperature $\left({ }^{\circ} \mathrm{C}\right)$ \\
\hline Fényes springs & $118-119$ & 81000 & 25200 & 22 \\
\hline $\begin{array}{l}\text { Tükör spring } \\
\text { (English park) }\end{array}$ & 138 & 33000 & 17400 & 20 \\
\hline $\begin{array}{l}\text { Pokol spring } \\
\text { (English park) }\end{array}$ & 140.8 & 27000 & 60 & 20.5 \\
\hline $\begin{array}{c}\text { Great spring under } \\
\text { the Castle }\end{array}$ & 118 & 10998 & 3400 & 21 \\
\hline $\begin{array}{c}\text { Springs of } \\
\text { Komárom street }\end{array}$ & $130-137$ & 1800 & 1440 & $11-20$ \\
\hline $\begin{array}{l}\text { Nagytavi } \\
\text { 'twin'spring }\end{array}$ & 127.3 & 1000 & 340 & 19 \\
\hline Lo Presti spring & 139.3 & 600 & 340 & 19 \\
\hline Kis-mosó spring & 136.5 & 504 & 236 & 18.5 \\
\hline Törökfürdő spring & 135.3 & 210 & 60 & 20.5 \\
\hline $\begin{array}{c}\text { Parochial-garden } \\
\text { spring }\end{array}$ & 126.8 & 180 & 480 & 15 \\
\hline $\begin{array}{l}\text { Springs of the } \\
\text { Castle }\end{array}$ & 135.3 & 60 & 180 & 15 \\
\hline $\begin{array}{l}\text { Piarist garden } \\
\text { spring }\end{array}$ & 128 & 36 & 1 & 18 \\
\hline Spring of Kőkút & 133.5 & 32.4 & 4 & \\
\hline Altogether & & 156420.4 & 49141 & \\
\hline
\end{tabular}

Tab. 1. Main data on the springs in Tata (after Ballabás 2004, Tab. 2).

I believe the discharge of the spring of Kökút köz and the springs of the Castle garden was too low to be able to supply the aqueduct of Brigetio, therefore it is more likely that the Romans used more abundant springs to supply the aqueduct, such as the Great spring under the Castle or the Fényes springs. These springs are located 118-119 m above sea level, therefore if we accept that the aqueduct ended in the area near the south gate of the legionary camp, which is at $107 \mathrm{~m}$ above sea level, then the slope of the aqueduct was $0,69 \%$ 。 or $0,76 \% .{ }^{33}$ This differs from the values suggested by Vitruvius $(5 \%)^{34}$ and Plinius $\left.(0,2 \%)\right)^{35}$

33 I count with $15.75 \mathrm{~km}$ long aqueduct based on the details given by Milos Berkovics-Borota (1886, 393).

34 Vitruvius: De Arch. 8.6.1.

35 Plinius: Nat. Hist. 31.57. 


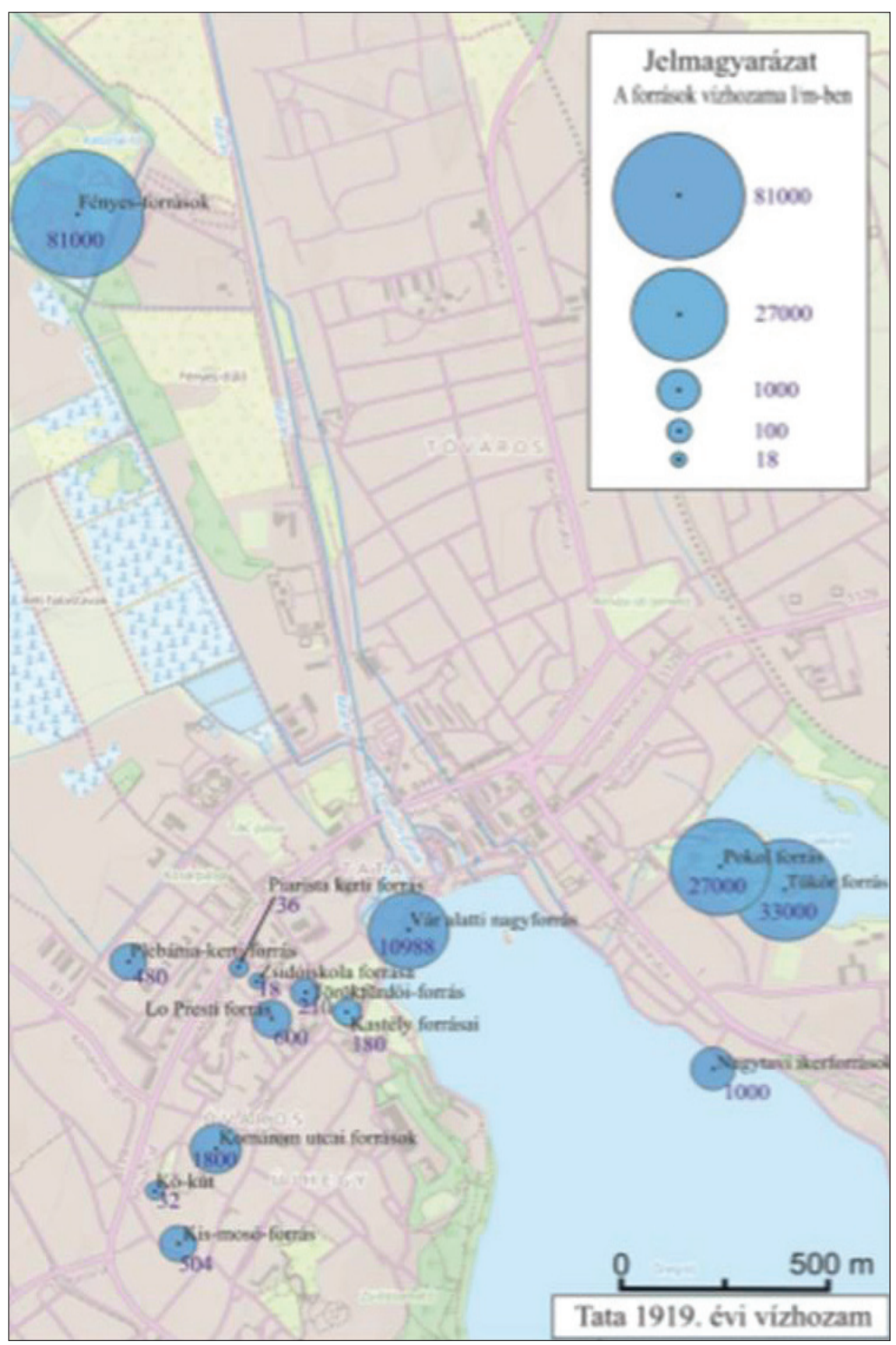

Fig. 7. The main springs of Tata and their discharge in 1919 (RÁtvai 2015, Fig. 13).

However, aqueducts with a similar slope can be found throughout the Roman Empire: for example the Appia in Rome, the aqueduct of Arles and the aqueduct of Trier. ${ }^{36}$

To sum up, according to the discharge values described above, I believe that the Romans used either the Fényes springs or the Great spring under the Castle to supply the aqueduct of Brigetio. In all probability, abundant springs were necessary to supply the baths on the territory of the canabae. The exact size of the baths is unknown, up to this day, $900 \mathrm{~m}^{2}$ of their territory has been excavated. ${ }^{37}$ Further study and archaeological surveys are necessary to definitely answer the question of the source of the aqueduct of Brigetio.

37 BARTus et al. 2016a, 338-339; BARTus et al. 2016b, 65-67. 


\section{The urban water distribution of Brigetio: lead and terracotta water pipes from Brigetio in the collection of the Hungarian National Museum}

Rudolf Gyulai is the first author to mention lead pipes found in Brigetio. According to his description, workmen found about 200 kilograms of lead near the castellum, located approximately in the middle of the western side of the camp. Probably these were the remains of the lead water pipes belonging to the urban water distribution system. ${ }^{38}$

As next, Kálmán Darnay mentions lead water pipes from Brigetio, who acquired an inscribed lead water pipe found in Ó-Szőny. Altogether four pieces were found but Darnay could only get the one with the inscription, the other pieces were sold by the finders. The following inscription is legible on the lead pipe: Claudius Valentinus feci $(t) \cdot{ }^{39}$ The inscription certainly refers to the plumbarius, the plumber who made the lead pipe. ${ }^{40}$

The name occurs on two other inscriptions in Pannonia. One of them is an altar from the Isis sanctuary in Savaria dated to A.D. $188{ }^{41}$

The other is a funerary inscription found near Alsó-Galla. ${ }^{42}$ The inscription states that it was set up by a certain Tib(erius) Cl(audius) Valentinus for his family members. According to the inscription he was a vet(eranus) ex c(ustode) a(rmorum) leg(ionis) I ad(iutricis), that is, he was connected to Brigetio. Unfortunately it is unknown if he was related to Claudius Valentinus plumbarius who is named on the inscription on the lead pipe.

László Barkóczi also mentions lead water pipes used in the urban water distribution system of Brigetio and he claims that the legionary camp was supplied by lead water pipes set at the western tower, next to the tower of the porta decumana and from here water ran onwards partly in lead water pipes and partly in a masonry channel on the surface. He mentions several rectangular pools still visible in his times, which were parts of the aqueduct channel running on the surface. ${ }^{43}$ These pools were possibly settling pools and also functioned as junctions in the system. ${ }^{44}$

Klára Póczy also claims that lead water pipes played a role in the urban water distribution system of Brigetio. She mentions the inscribed lead pipe acquired by Kálmán Darnay and referring to a verbal statement of László Barkóczi she mentions some lead filtering equipment belonging to the collection of the Hungarian National Museum which was found in Szőny. ${ }^{45}$ Unfortunately during my research in the Hungarian National Museum I could not find any such filtering equipment.

In 2018 I had the opportunity to carry out research in the Hungarian National Museum, I studied the inventory books and the Roman collection. ${ }^{46}$ In the Roman collection there are altogether 12

38 Gyulai 1885.

39 DARNAY 1897.

40 Bruun 1991, 87-95; Hodge 1992, 311; CoOley 2012, 190.

41 RIU 22.

42 RIU 696; BARKóczi 1964, 265.

43 BARKóczi 1949, 71.

44 Hodge 1992, 120-121, Fig. 74.

45 Póczy 1980, 78, Fig. 70.

46 Hereby I would like to express my gratitude to Zsolt Mráv and Tamás Szabadváry for supporting my research in the Hungarian National Museum. 
lead pipes which could be connected to Brigetio (Cat. 1-12). I recorded the length, both the inner and outer diameter of the lead water pipes and also the thickness of the lead sheet they were made of. I studied the production technique and categorized them according to the typology of André Cochet and Jørgen Hansen (Fig. 8). ${ }^{47}$ The sizes of the lead pipes are various, their length is usually between 60 and $80 \mathrm{~cm}$, the shortest one is $35,5 \mathrm{~cm}$ long (Cat. 7), the longest one is $283 \mathrm{~cm}$ (Cat. 1). The outer diameter is usually around $10 \mathrm{~cm}$, the smallest diameter is $7 \mathrm{~cm}$ (Cat. 5), while the largest diameter is $16-17 \mathrm{~cm}$ (Cat. 3), the inner diameters follow the outer diameter sizes.

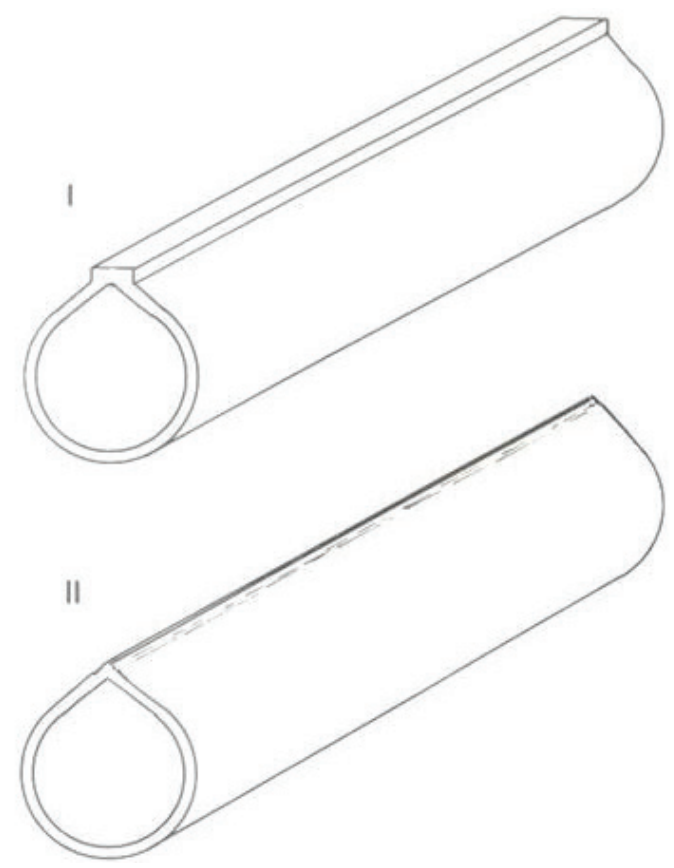

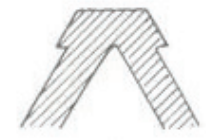

A

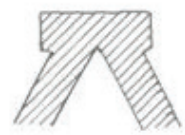

B

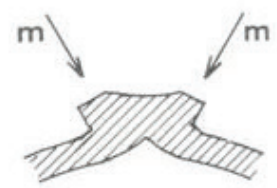

$\mathrm{B}^{\prime}$

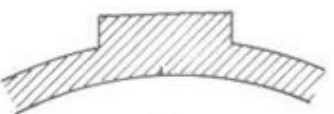

$\mathrm{D}$

Fig. 8. Typology of lead water pipes (Cochet - HANsen 1986, Fig. 5-6).

The thickness of the lead sheet used in production of the lead pipes varies between $0,3-0,6 \mathrm{~cm}$. Typologically all the lead pipes belong to Cochet-Hansen 1986 Type I, as they are soldered by a lead seam. The pipes can be divided into subtypes according to the cross-sectional shape of the seam. Most of the pipes (Cat. 1, 2, 4, 5, 6, 9, 11, 12) belong to the Cochet-Hansen 1986 Type I. A, as the intersection of the pipes is pear-shaped and the cross-sectional shape of the soldering seam is trapezoid with a base wider than the top. Three of the lead pipes (Cat. 7, 8, 10) belong to the Cochet-Hansen 1986 Type I. C, as the intersection of the pipes is pearshaped and the cross-sectional shape of the soldering seam is trapezoid with a top wider than the base. Only a single lead pipe (Cat. 3) belongs to the Cochet-Hansen 1986 Type I. D, as it has a circular intersection and the cross-sectional shape of the soldering seam is rectangular.

According to the above described material it can be concluded, with regard to the production technique, that in case of the lead pipes used in Brigetio the technique of jointing the lead sheet was soldering by setting in a lead seam, and in case of most of the pipes (67\%), the soldering was made according to Cochet-Hansen 1986 Type I. A.

There was only a single inscribed lead pipe (Cat.3) in the collection of the Hungarian National Museum. The relief inscription was stamped on the lead pipe, it is $27 \mathrm{~cm}$ long and the height of 
the letters is $2.8-3 \mathrm{~cm}$ (Fig. 10-11). The partly damaged inscription is the following: LEG.I-A[- - -]R.PF, therefore it can be read as $\operatorname{Leg}($ io $)$ I A[diut $] r(i x) P($ ia) F(idelis). Such abbreviation of the name of Legio I Adiutrix does not occur anywhere else in the inscribed material. According to the inscription we can conclude that the Legio I Adiutrix took part in the construction of the aqueduct and the urban water distribution system. László Barkóczi also mentions lead water pipes bearing the stamps of Legio I Adiutrix, and we do not know about stamps or inscriptions of any other legio that could be connected to the aqueduct of Brigetio. Therefore, it seems probable that the construction of the aqueduct and the urban water distribution system of Brigetio took place after the arrival of Legio I Adiutrix, that is, after $118-119 \mathrm{AD},{ }^{48}$ possibly simultaneously with the construction of the legionary camp, as László Barkóczi also claims. ${ }^{49}$

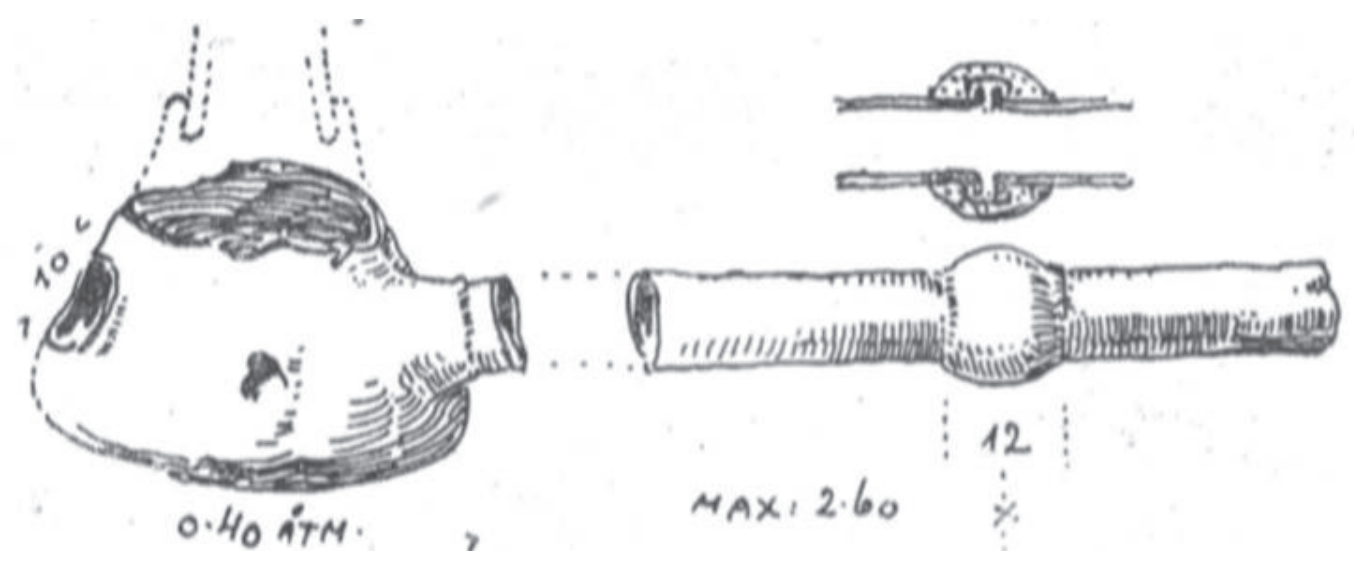

Fig. 9. Lead junction vessel from Aquincum (Foerk 1923, Fig. 7).

In the collection of the Hungarian National Museum there is a lead junction vessel (Cat. 13) which was used for distribution of the lead pipes. Three lead pipes fitted in the holes of the junction vessel. On its top there is a large, $23-24 \mathrm{~cm}$ diameter circular hole which was probably used for cleaning and maintenance and originally had a cover which could be removed if necessary (Fig. 15). A similar junction vessel (Fig. 10) was published by Ernő Foerk from Aquincum. ${ }^{50}$

The above-mentioned lead pipes were acquired by the Hungarian National Museum partly as gifts and partly as purchase. Two lead pipes and the lead junction vessel (Cat. 1-2, 13) were gifts of Mrs. Tivadar Tusla in 1885, ${ }^{51}$ the rest of the lead pipes (Cat. 3-12) were purchased by the museum from Samu Tachauer in $1893 .{ }^{52}$

During my research in the Hungarian National Museum I checked all the inventory books, and it came to light that previously the museum owned more lead water pipes from Brigetio, which were however lost later.

Inventory numbers MNM 15.1893.1-3 refer to three lead water pipes soldered by a lead seam, $179 \mathrm{~cm}, 75 \mathrm{~cm}$ and $44 \mathrm{~cm}$ long, with 5-8 $\mathrm{cm}$ diameter. The lead pipes were purchased from Ádám Lengyel in $1893 .{ }^{53}$

48 BoRHy 2012, 26-27.

49 BARKóczi 1949, 70.

50 FOERK 1923, 42-43, Figs 6-7.

51 Inventory book of the Hungarian National Museum 1885.

52 Inventory book of the Hungarian National Museum 1893.

53 Inventory book of the Hungarian National Museum 1893. 


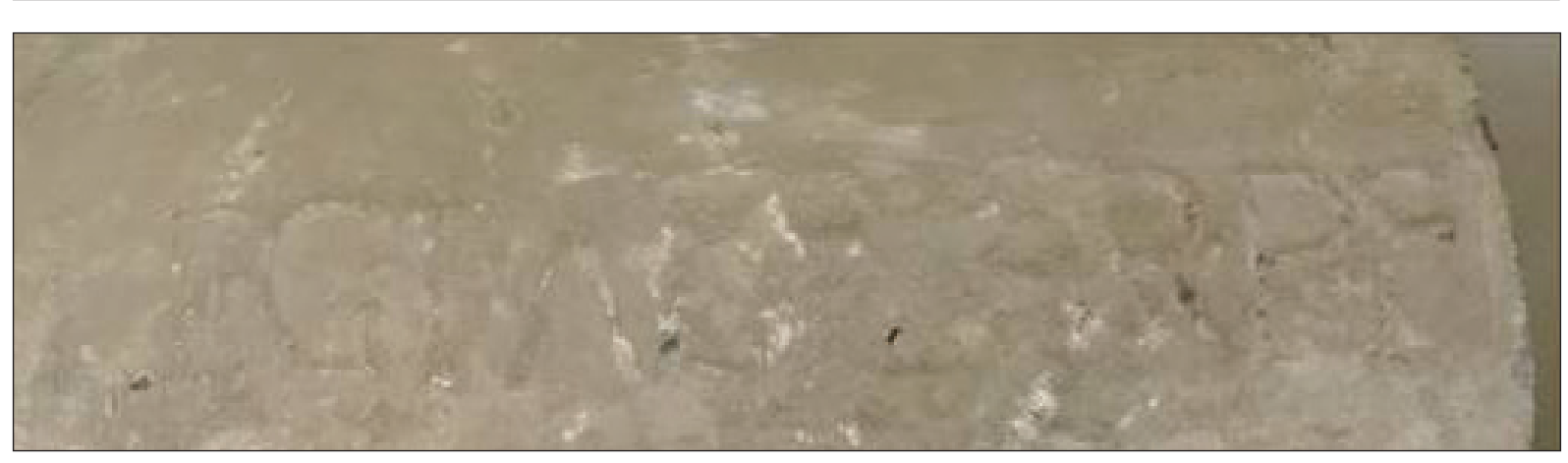

Fig. 10. Photo of the inscription of the lead water pipe from Brigetio (Cat. 3).

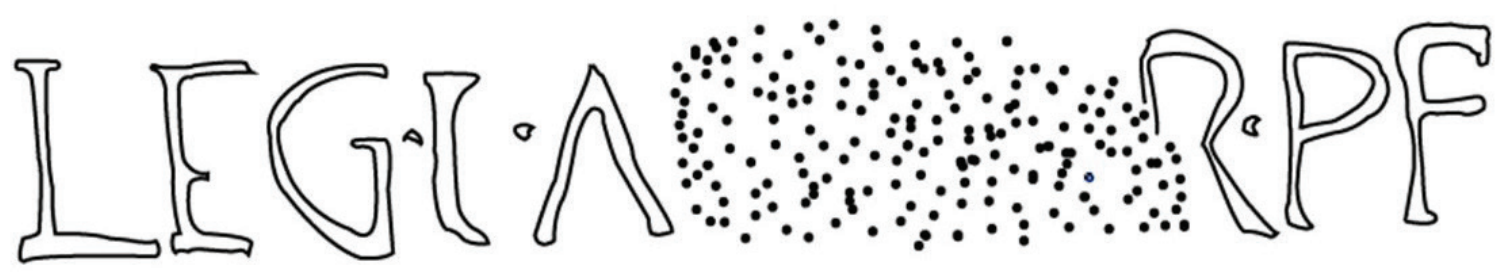

Fig. 11. The inscription of the lead water pipe from Brigetio (Cat. 3).

Inventory numbers MNM 152.1885.397-398 refer to $9.6 \mathrm{~cm}$ and $3 \mathrm{~cm}$ long lead water pipes which got to the museum as a gift by Genie Direktion from Szőny in $1885 .{ }^{54}$ Inventory numbers MNM 28.1952.1-7 also refer to lead water pipes which were brought to the museum by László Barkóczi in 1952. The lead pipes were found along the road in front of the porta decumana of the legionary camp during ploughing in the garden of MASZOLAJ. Inventory number MNM 28.1952.1 refers to a $47 \mathrm{~cm}$ long lead water pipe made of $1-1.5 \mathrm{~cm}$ thick lead sheet.

Inventory number MNM 28.1952 .2 refers to a $78 \mathrm{~cm}$ long lead pipe with $28 \times 17 \mathrm{~cm}$ diameter soldered by a rectangular lead seam.

Inventory number MNM 28.1952 .3 refers to a $80 \mathrm{~cm}$ long lead pipe with $36 \times 19 \mathrm{~cm}$ diameter, also soldered by a lead seam, $4.5 \mathrm{~cm}$ from which an inscription is legible: VTERE FI, that is, Utere $f(e l) i(x)$. Approximately in the middle of the lead pipe, $13 \mathrm{~cm}$ from the seam an X sign was placed.

Inventory number MNM 28.1952.5 refers to a lead pipe $99 \mathrm{~cm}$ long with $30 \times 10 \mathrm{~cm}$ diameter, soldered by a lead seam and equipped with a $14 \mathrm{~cm}$ wide soldered lead sleeve. $9 \mathrm{~cm}$ from the lead sleeve a VX sign was placed.

Inventory number MNM 28.1952.6 refers to a lead pipe $102 \mathrm{~cm}$ long with $18 \times 28 \mathrm{~cm}$ diameter and a $15 \mathrm{~cm}$ wide soldered lead sleeve. On one side of the lead sleeve relief signs can be noticed. Both ends of the lead pipe were cut off.

Inventory number 28.1952. refers to a lead pipe $113 \mathrm{~cm}$ long with $29 \times 17 \mathrm{~cm}$ diameter, again soldered by a lead seam, on one side it bore linear signs of $42 \mathrm{~cm}$ length. ${ }^{55}$

According to the descriptions of the inventory books the above-mentioned lead pipes all belong to the Cochet-Hansen 1986 Type I, as they were soldered by a lead seam. The X and VX 
signs probably refer to numbers that might have indicated the weight of the lead sheet or they could help the work of the plumbarius by providing useful information during installation. ${ }^{56}$

Beside the lead water pipes, the Hungarian National Museum owns altogether five terracotta water pipes that were found in Brigetio (Cat. 14-18). These terracotta water pipes were given to the museum as a gift by Mrs. Tivadar Tussla together with the above-mentioned lead pipes in 1885. The length of the terracotta water pipes varies from $33 \mathrm{~cm}$ to $67 \mathrm{~cm}$. The outer diameter of their narrow end varies from $7.1 \mathrm{~cm}$ to $9.5 \mathrm{~cm}$, the outer diameter of their wide end varies from $12 \mathrm{~cm}$ to $13 \mathrm{~cm}$. All the terracotta pipes are narrowing on one end thus they could slide into each other. The thickness of the sidewalls varies from $1.1 \mathrm{~cm}$ to $2.2 \mathrm{~cm}$. The intersection of the pipes is circular and they often bear stains of mortar and traces of secondary burning.

The terracotta water pipes from Brigetio prove that beside the lead water pipes also terracotta water pipes were used in the construction of the urban water distribution system of Brigetio.

Similarly to the case of the lead water pipes, according to the inventory books of the museum, originally more terracotta water pipes from Brigetio belonged to the collection, however most of them are lost by now unfortunately.

Inventory number MNM 65.1885.224 does not only refer to the five terracotta pipes described in the catalogue, originally it refers to ten pieces. Unfortunately the sizes and the description about the extra pieces is not included in the inventory book. ${ }^{57}$

Inventory number MNM 65.1885.284 refers to altogether 24 pieces of terracotta water pipes, $37 \mathrm{~cm}$ long and $15 \mathrm{~cm}$ wide apiece. According to the description they were not stamped. ${ }^{58}$

Inventory number MNM 65.1885.120 refers to a stamped terracotta water pipe. According to the description it bore the stamp of Legio I Adiutrix in the following abbreviated form: LEG I AD. Unfortunately neither the sizes of the terracotta pipe, nor the size of the stamp is given. ${ }^{59}$ This stamped terracotta water pipe supports the above mentioned suggestion that the aqueduct of Brigetio and the urban water distribution system was constructed by the Legio I Adiutrix.

In conclusion, according to the studied material we can claim that in the urban water distribution system of Brigetio the Romans used both lead water pipes and terracotta water pipes. Based on the inscriptions legible on water pipes, the Legio I Adiutrix took part in the construction of the urban water distribution system of Brigetio and probably the construction of the whole water supply system took place after the arrival of the Legio I Adiutrix, therefore after 118-119 AD, at least by now we have no evidence to suppose otherwise. ${ }^{60}$

\section{References}

BALlABÁs G. 2004: Visszatérő karsztforrásokkal kapcsolatos településfejlesztési és környezetvédelmi lehetőségek és veszélyek Tata város példáján. Geográfus Doktoranduszok VIII. Országos Konferenciája, Szeged. http:geogr.elte.hu/TGF/TGF_Cikkek/ballabas2.pdf (online access: 02. 11. 2017).

56 BRUUn 1991, 40, 44-55.

57 Inventory book of the Hungarian National Museum 1885.

58 Inventory book of the Hungarian National Museum 1885.

59 Inventory book of the Hungarian National Museum 1885.

60 Hereby I would like to express my gratitude to Prof. László Borhy, my director of studies, for his advice and support in my research. 
BArkóczi, L. 1949: A brigetioi tábor és canabae topográfiája. Antiquitas Hungarica 3, 67-72.

BArkóczi, L. 1964: The Population of Pannonia from Marcus Aurelius to Diocletian. Acta Archaeologica Academiae Scientiarum Hungaricae 16, 257-356.

Bartus, D. - Borhy, L. - CZAjLik, Z. 2016b: Recent research in the canabae and legionary fortress of Brigetio (2014-2015). In: BEszÉDEs, J. (ed.): Legionary fortress and canabae legionis in Pannonia. International Archaeological Conference. 16-17. November, 2015. Aquincum Nostrum II. 7. Budapest, 63-72.

BArtus, D. - Borhy, L. - Sey, N. - SzÁmadó, E. 2016a: Short report on the excavations in Brigetio in 2016. Dissertationes Archaeologicae 3/4, 338-349.

BÉL, M. 1989: Komárom vármegye. Az újkori Magyarország földrajzi-történelmi ismertetése, Csallóközi Kiskönyvtár, Pozsony.

Berkovics-Borota, M. 1886: Ásatásom az ó-szőnyi római táborban. Archaeologiai Értesitő 6, 392-397.

Borhy, L. 2012: Die Legio XI Claudia im pannonischen Brigetio (Komárom/Szőny, Ungarn). In: KovÁcs, P. - Szabó, Á. (eds.): Studia Epigraphica Pannonica IV. Budapest, 23-36.

Bruun, C. 1991: The Water Supply of Ancient Rome. A Study of Roman Imperial Administration. Commentationes Humanarum Litterarum 93. Helsinki.

Cochet, A. - Hansen, J. 1986: Conduites et objets de plomb Gallo-Romains de Vienne (Isère). Paris.

Cooley, A. E. 2012: The Cambridge Manual of Latin Epigraphy. New York.

DARnay, K. 1897: Vízvezető ólomcső Bregetióból. Archaeologiai Értesítő 17, 96.

FoERK, E. 1923: Az óbudai aquaeductus. Budapest Régiségei 10, 35-55.

FogarasI, S. 2001: Visszatérnek-e a Tatai források? Földrajzi Konferencia. Szeged. http: geography.hu/ mfk2001/cikkek/Fogarasi.pdf (online access: 29. 10. 2017).

GyulaI, R. 1885: A Bregetiumi vízvezetékről. Archaeologiai Értesítő 5, 332-335.

GyulaI, R. 1886: Második levele a bregetiumi vízvezetékről. Archaeologiai Értesitőo 6, 348-350.

Hodge, T. A. 1992: Roman Aqueducts \& Water Supply. London.

Horusitzky, H. 1923: Tata és Tóváros környékének hidrogeológiája és közgazdasági jövője. A Magyar Királyi Földtani Intézet Évkönyve 25/3. Budapest.

КомJÁtı, M. 1944-1945: Mikoviny Sámuel jelentése tatavidéki római leletekről. Archaeologiai Értesitő 3/5-6, 249-255.

Marsigli, L. F. 1726: Danubius Pannonico-Mysicus I. Amsterdam.

PAulovics, S. 1941: Funde und Forschungen in Brigetio (Szőny). Laurae Aquincenses memoria Valentini Kuzsinszky dicatae, I-II. Dissertationes Pannonicae II/10-11, 118-164.

Póczy, K. 1980: Közmüvek a római kori Magyarországon. Budapest.

RÁTvAI, D. 2015: Tata és Tóváros karsztforrásainak vízhozam változása térképen ábrázolva. MA thesis. Budapest.

Viczián, I. - HoRváth, F. 2016: A tatai mocsarak a római korban és Mikoviny Sámuel lecsapoló munkája. Földrajzi Értesító 55, 257-272.

\section{Catalogue}

\section{Cat. 1}

Lead water pipe.

Inv. no.: MNM 65.1885.89. Acquisition: gift from Mrs. Tivadar Tussla. Sizes: $1 .: 283 \mathrm{~cm}$; d. outer: $10-9 \mathrm{~cm}$; d. inner: $8.6-9.5 \mathrm{~cm}$; t.: $0.4-0.5 \mathrm{~cm}^{61}$

61 Abbreviations: l.: length; d.: diameter; w.: width; h.: height; t.: thickness of sidewalls; Inv. no.: Inventory number. 
Description: fragment of a lead water pipe with pear-shaped intersection. It is soldered by a lead seam. According to the typology of Cochet-Hansen 1986 it belongs to Type I.A as the intersection of the pipe shows a pear-shape and the cross-sectional shape of the soldering seam is trapezoid with a base wider than the top. It shares the same inventory number with Cat. 2.

Cat. 2

Lead water pipe.

Inv. no.: MNM 65.1885.89. Acquisition: gift from Mrs. Tivadar Tussla. Sizes: 1.: $120 \mathrm{~cm}$; d. outer: 10$7 \mathrm{~cm}$; d. inner: $6.5-9.5 \mathrm{~cm}$; t.: $0.4-0.5 \mathrm{~cm}$.

Description: fragment of a lead water pipe with pear-shaped intersection. It is soldered by a lead seam. According to the typology of Cochet-Hansen 1986 it belongs to Type I.A as the intersection of the pipe shows a pear shape and the cross-sectional shape of the soldering seam is trapezoid with a base wider than the top. It shares the same inventory number with Cat. 1.

Cat. 3

Lead water pipe with an inscription (Figs 10-11).

Inv. no.: MNM 2.1893? Acquisition: purchased from Samu Tachauer. Sizes: $1 .: 66 \mathrm{~cm}$; d. outer: 16-17 cm; d. inner: $15.5-16 \mathrm{~cm}$; t.: $0.7-1 \mathrm{~cm}$.

Description: fragment of a lead water pipe with circular intersection. It is soldered by a lead seam. According to the typology of Cochet-Hansen 1986 it belongs to Type I.D, as it has a circular intersection and the cross-sectional shape of the soldering seam is rectangular. Relief inscription was stamped on the lead pipe, it is $27 \mathrm{~cm}$ long and the height of the letters is $2.8-3 \mathrm{~cm}$. The partly damaged inscription is the following: LEG.I.A[- - - ]R.PF, therefore can be read as Leg(io) I A[diut $] r(i x) P($ ia) F(idelis).

\section{Cat. 4}

Lead water pipe.

Inv. no.: MNM 2.1893? Acquisition: purchased from Samu Tachauer. Sizes: 1.: $81 \mathrm{~cm}$; d. outer: $11 \mathrm{~cm}$; d. inner: $10.5 \mathrm{~cm}$; t.: $0.4 \mathrm{~cm}$.

Description: fragment of a lead water pipe with pear-shaped intersection. It is soldered by a lead seam. According to the typology of Cochet-Hansen 1986 it belongs to Type I.A as the intersection of the pipe shows a pear shape and the cross-sectional shape of the soldering seam is trapezoid with a base wider than the top.

\section{Cat. 5}

Lead water pipe (Fig. 12).

Inv. no.: MNM 2.1893? Acquisition: purchased from Samu Tachauer. Sizes: $1 .: 76 \mathrm{~cm}$; d. outer: $7 \mathrm{~cm}$; d. inner: $6.5-4.5 \mathrm{~cm}$; t.: $0.5-0.6 \mathrm{~cm}$.

Description: fragment of a lead water pipe with pear-shaped intersection. It is soldered by a lead seam. According to the typology of Cochet-Hansen 1986 it belongs to Type I.A as the intersection of the pipe shows a pear shape and the cross-sectional shape of the soldering seam is trapezoid with a base wider than the top.

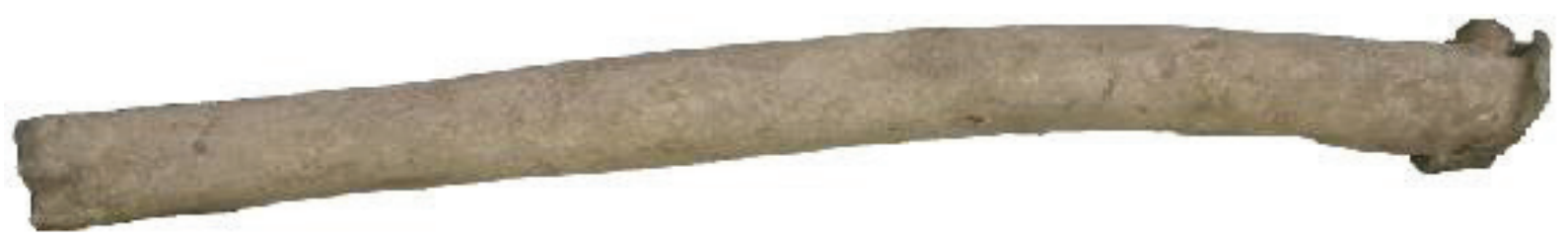

Fig. 12. Lead water pipe from Brigetio (Cat. 5). 
Cat. 6

Lead water pipe.

Inv. no.: MNM 2.1893? Acquisition: Purchased from Samu Tachauer. Sizes: $1 .: 76 \mathrm{~cm}$; d. outer: 8-4 cm; d. inner: $7.2-3 \mathrm{~cm}$; t.: $0.3-0.4 \mathrm{~cm}$.

Description: fragment of a lead water pipe with pear-shaped intersection. It is soldered by a lead seam. According to the typology of Cochet-Hansen 1986 it belongs to Type I.A as the intersection of the pipe shows a pear shape and the cross-sectional shape of the soldering seam is trapezoid with a base wider than the top.

\section{Cat. 7}

Lead water pipe (Fig. 13).

Inv. no.: MNM 2.1893.9. Acquisition: purchased from Samu Tachauer. Sizes: 1.: $35.5 \mathrm{~cm}$; d. outer: 9.5$7.5 \mathrm{~cm}$; d. inner: $9-7 \mathrm{~cm}$; t.: $0.3-0.4 \mathrm{~cm}$.

Description: fragment of a lead water pipe with pear-shaped intersection. It is soldered by a lead seam. According to the typology of Cochet-Hansen 1986 it belongs to Type I.C as the intersection of the pipe shows a pear shape and the cross-sectional shape of the soldering seam is trapezoid with a top wider than the base.

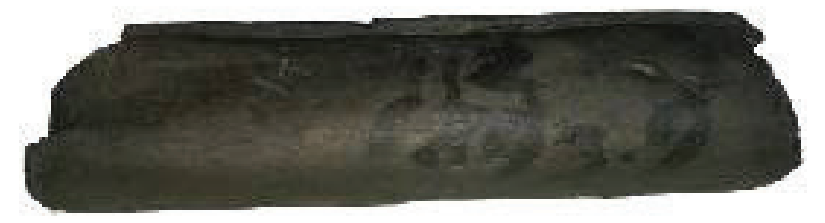

Fig. 13. Lead water pipe from Brigetio (Cat. 7).

\section{Cat. 8}

Lead water pipe.

Inv. no.: MNM 2.1893.8. Acquisition: purchased from Samu Tachauer. Sizes: 1.: $69 \mathrm{~cm}$; d. outer: 10.5$10 \mathrm{~cm}$; d. inner: $9-9.5 \mathrm{~cm}$; t.: $0.4-0.5 \mathrm{~cm}$.

Description: fragment of a lead water pipe with pear-shaped intersection. It is soldered by a lead seam. According to the typology of Cochet-Hansen 1986 it belongs to Type I.C as the intersection of the pipe shows a pear shape and the cross-sectional shape of the soldering seam is trapezoid with a top wider than the base.

Cat. 9

Lead water pipe.

Inv. no.: MNM 2.1893.1. Acquisition: purchased from Samu Tachauer. Sizes: $1 .: 77 \mathrm{~cm}$; d. outer: 13$10.5 \mathrm{~cm}$; d. inner: $12.5-9.8 \mathrm{~cm}$; t.: $0.4-0.5 \mathrm{~cm}$.

Description: fragment of a lead water pipe with pear-shaped intersection. It is soldered by a lead seam. According to the typology of Cochet-Hansen 1986 it belongs to Type I.A as the intersection of the pipe shows a pear shape and the cross-sectional shape of the soldering seam is trapezoid with a base wider than the top.

\section{Cat. 10}

Lead water pipe.

Inv. no.: MNM 2.1893.2. Acquisition: purchased from Samu Tachauer. Sizes: $1 .: 134 \mathrm{~cm}$; d. outer: 10$9 \mathrm{~cm}$; d. inner: $9.6-8.5 \mathrm{~cm}$; t.: $0.4-0.5 \mathrm{~cm}$.

Description: fragment of a lead water pipe with pear-shaped intersection. It is soldered by a lead seam. According to the typology of Cochet-Hansen 1986 it belongs to Type I.C as the intersection of the 
pipe shows a pear shape and the cross-sectional shape of the soldering seam is trapezoid with a top wider than the base.

Cat. 11

Lead water pipe.

Inv. no.: MNM 2.1893.4. Acquisition: purchased from Samu Tachauer. Sizes: 1.: $76.5 \mathrm{~cm}$, d. outer: 11$9 \mathrm{~cm}$; d. inner: $10.3-8.5 \mathrm{~cm}$, t.: $0.6-0.5 \mathrm{~cm}$.

Description: fragment of a lead water pipe with pear-shaped intersection. It is soldered by a lead seam. According to the typology of Cochet-Hansen 1986 it belongs to Type I.A as the intersection of the pipe shows a pear shape and the cross-sectional shape of the soldering seam is trapezoid with a base wider than the top.

Cat. 12

Lead water pipe (Fig. 14).

Inv. no.: MNM 2.1893.5. Acquisition: purchased from Samu Tachauer. Sizes: $1 .: 69 \mathrm{~cm}$, d. outer: $12.5-$ $9 \mathrm{~cm}$; d. inner: $12-8.5 \mathrm{~cm}$; t.: $0.5 \mathrm{~cm}$.

Description: fragment of a lead water pipe with pear-shaped intersection. It is soldered by a lead seam. According to the typology of Cochet-Hansen 1986 it belongs to Type I.A as the intersection of the pipe shows a pear shape and the cross-sectional shape of the soldering seam is trapezoid with a base wider than the top. On one end of the lead pipe a 7-8 cm wide lead sleeve is inserted. A 3-10 cm long fragment of the other lead pipe joined by the lead sleeve is also visible, all the other sizes and the type of it are the same as those of the above described lead pipe.

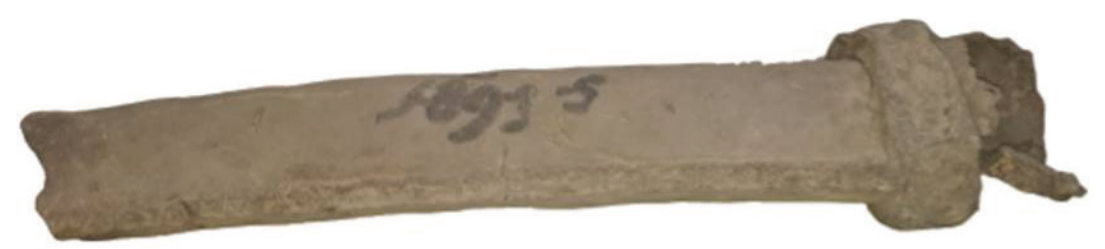

1
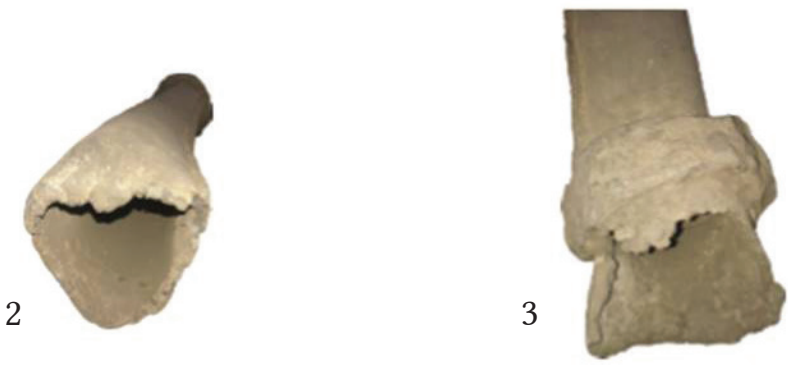

Fig. 14. Lead water pipe with lead sleeve from Brigetio (Cat. 12).

Cat. 13

Lead junction vessel (Fig. 15).

Inv. no.: MNM 65.1885.92. Acquisition: gift from Mrs. Tivadar Tussla. Sizes: w.: $57 \mathrm{~cm}$; h.: $40 \mathrm{~cm}$; t.: $0.5-0.9 \mathrm{~cm}$.

Description: lead junction vessel which was used for distribution of the lead pipes. Three lead pipes fitted in the holes of the junction vessel, the first of the holes is $12 \mathrm{~cm}$ in diameter, the second is $11 \mathrm{~cm}$ in diameter and a 16-20 cm long fragment of the lead water pipe which was inserted in it can still be seen. The third hole of the vessel is $8-10 \mathrm{~cm}$ in diameter. On the top it has a largecircular hole of $23-24 \mathrm{~cm}$ diameter which was probably used for cleaning and maintenance and originally had a cover which could be removed if necessary. 

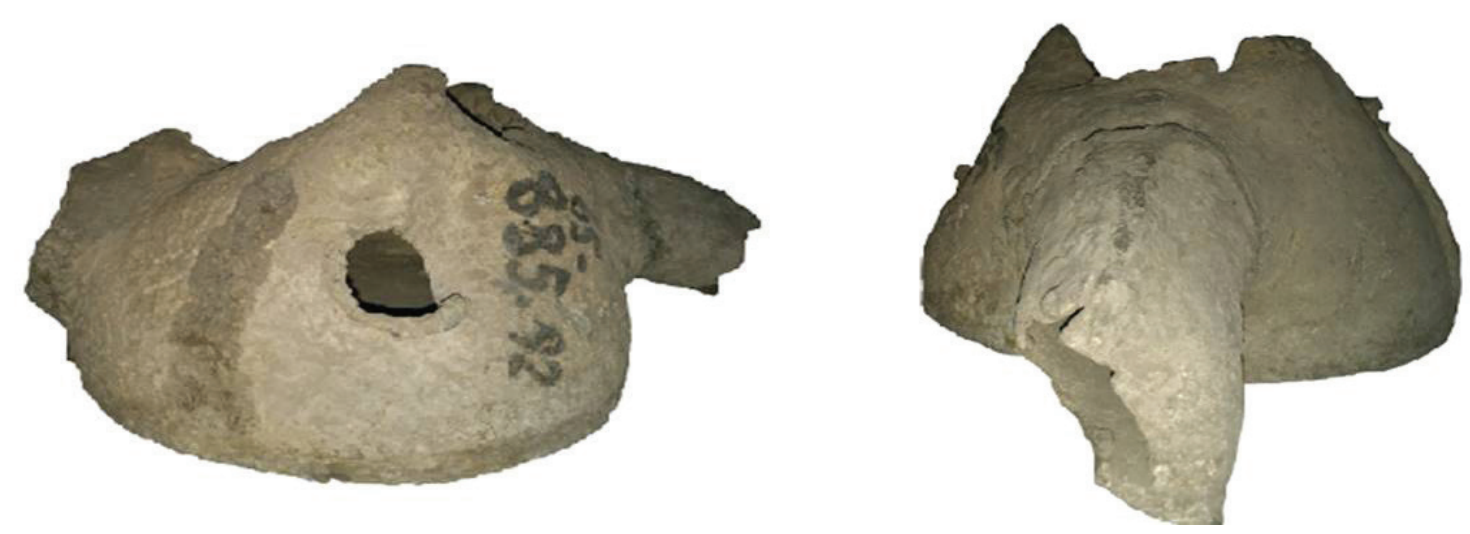

Fig. 15. Lead junction vessel from Brigetio (Cat. 13).

Cat. 14

Terracotta water pipe (Fig. 16.1-3).

Inv. no.: MNM 65.1885.224A. Acquisition: gift from Mrs. Tivadar Tussla. Sizes: 1.: $48.5 \mathrm{~cm}$, narrow end: d. outer: $8 \mathrm{~cm}$; d. inner: $5.8-2.9 \mathrm{~cm}$; wide end: d. outer: $12 \mathrm{~cm}$; d. inner: $9.2 \mathrm{~cm}$; t.: $1.2-1.4 \mathrm{~cm}$.

Description: terracotta water pipe slightly narrowing from one end to the other. Thanks to the narrowing end it could be slid to another terracotta pipe of the appropriate size. It has a circular intersection. On the brim of the narrow end, stains of mortar can be seen. On the outer surface of the pipe there are black traces of secondary burning and stains of mortar. It is nearly complete, only the brim of the narrow end is partly broken.

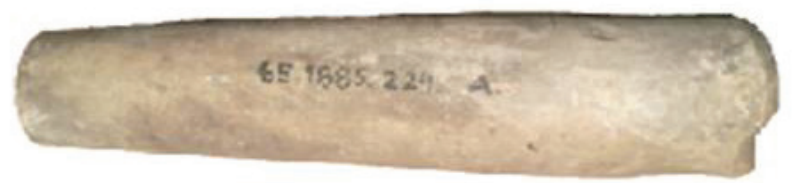

2

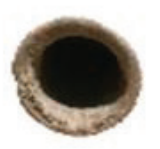

3

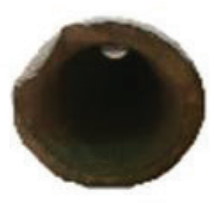

4
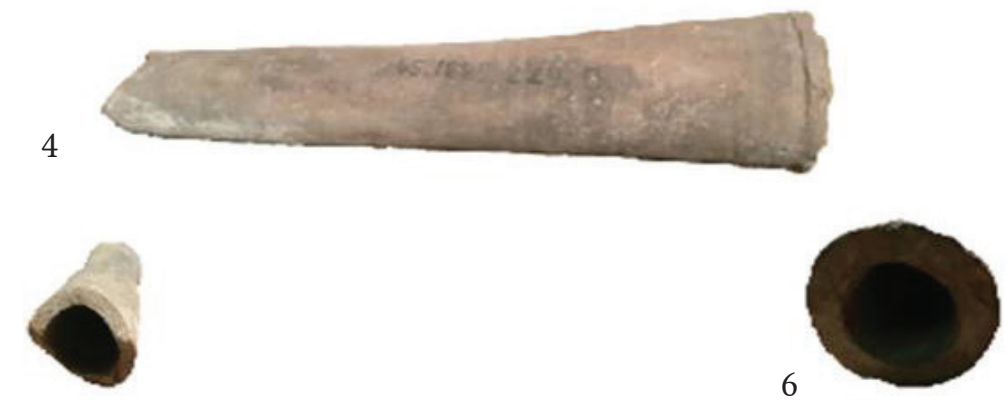

Fig. 16. Terracotta water pipes from Brigetio (Cat. 14-15). 
Cat. 15

Terracotta water pipe (Fig. 16.4-6).

Inv. no.: MNM 65.1885.224.B. Acquisition: gift from Mrs. Tivadar Tussla. Sizes: $1 .: 47 \mathrm{~cm}$; narrow end: d. outer: $7.1 \mathrm{~cm}$; d. inner: $5 \mathrm{~cm}$; wide end: d. outer: $12 \mathrm{~cm}$; d. inner: $7.3 \mathrm{~cm}$; t.: $1.1-2.4 \mathrm{~cm}$.

Description: terracotta water pipe slightly narrowing from one end to the other. Thanks to the narrowing end it could be slid into another terracotta pipe of the appropriate size. It has a circular intersection. On the outer surface of the pipe there are black traces of secondary burning and stains of mortar. It is fragmentary, the brim of the narrow end is broken.

Cat. 16

Terracotta water pipe (Fig. 17.1-3).

Inv. no.: MNM 65.1885.224.C. Acquisition: gift from Mrs. Tivadar Tussla. Sizes: 1.: $42.5 \mathrm{~cm}$; narrow end: d. outer: $8 \mathrm{~cm}$; d. inner: $6.2 \mathrm{~cm}$; wide end: d. outer: $13 \mathrm{~cm}$; d. inner: $8.7 \mathrm{~cm}$; t.: $2-1.2 \mathrm{~cm}$.

Description: terracotta water pipe slightly narrowing from one end to the other. Thanks to the narrowing end it could be slid into another terracotta pipe of the appropriate size. It has a circular intersection. On the outer surface of the pipe there are black traces of secondary burning and stains of mortar. It is fragmentary, partly broken on the wide end.

\section{Cat. 17}

Terracotta water pipe (Fig. 17.4-6).

Inv. no.: MNM 65.1885.224.D. Acquisition: gift from Mrs. Tivadar Tussla. Sizes: $1 .: 34 \mathrm{~cm}$; narrow end: d outer: $8 \mathrm{~cm}$; d. inner: $5.2 \mathrm{~cm}$; wide end: $d$. outer: $12 \mathrm{~cm}$; d. inner: $8 \mathrm{~cm}$; t.: $2-1.4 \mathrm{~cm}$.

Description: terracotta water pipe slightly narrowing from one end to the other. Thanks to the narrowing end it could be slid into another terracotta pipe of the appropriate size. It has a circular intersection. It is fragmentary, partly broken on both ends.
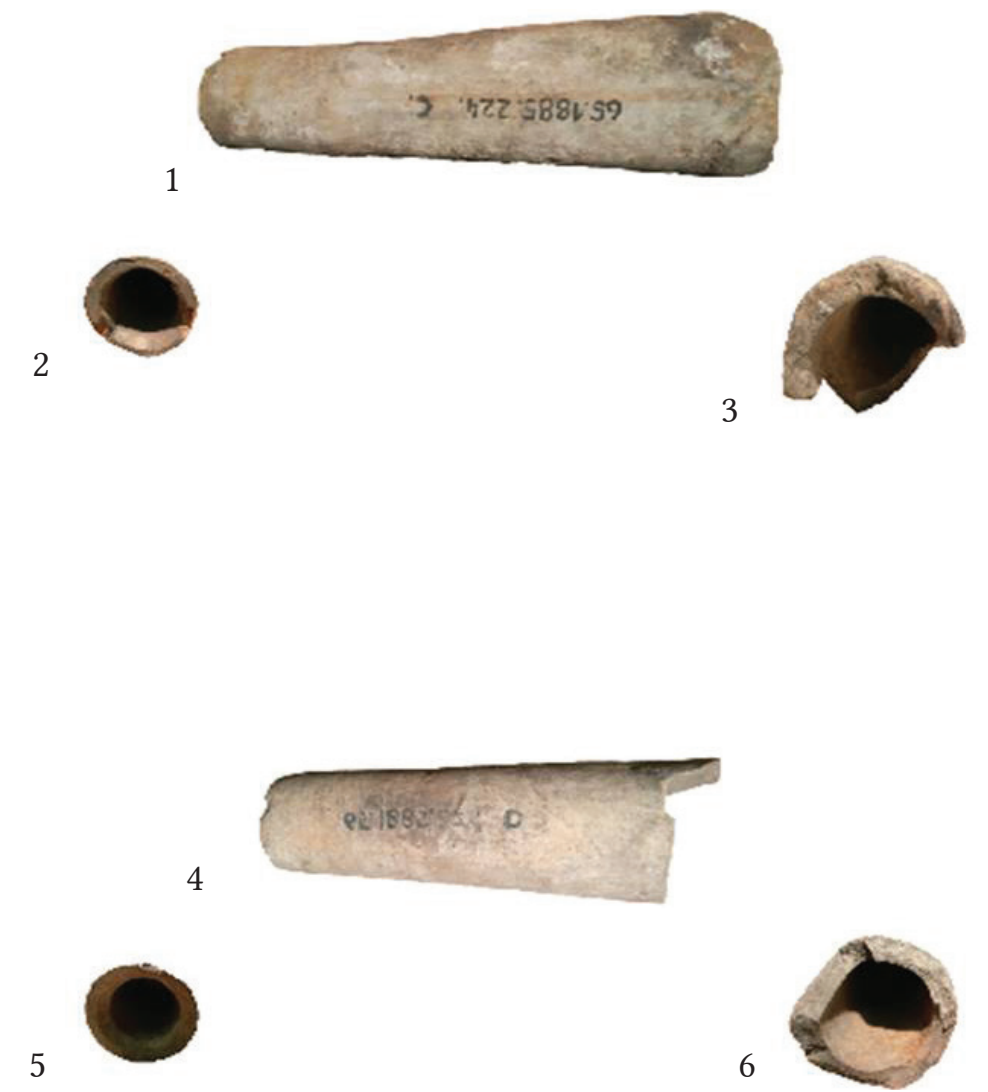

6

Fig. 17. Terracotta water pipes from Brigetio (Cat. 16-17). 
1

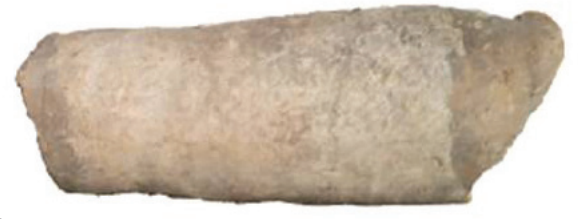

2

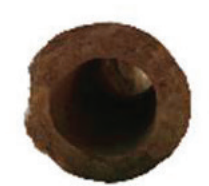

3

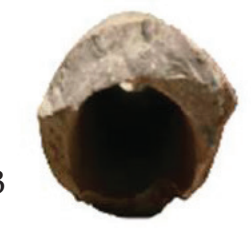

Fig. 18. Terracotta water pipe from Brigetio (Cat. 18).

\section{Cat. 18}

Terracotta water pipe (Fig. 18).

Inv. no.: MNM 65.1885.224.E. Acquisition: gift from Mrs. Tivadar Tussla. Sizes: 1.: $33 \mathrm{~cm}$; narrow end: d. outer: $9.5 \mathrm{~cm}$; d. inner: $6 \mathrm{~cm}$; wide end: d. outer: $12 \mathrm{~cm}$; d. inner: $8.1 \mathrm{~cm}$; t.: $1.8-2 \mathrm{~cm}$.

Description: terracotta water pipe slightly narrowing from one end to the other. Thanks to the narrowing end it could be slid into another terracotta pipe of the appropriate size. It has a circular intersection. On the outer surface of the pipe there are black traces of secondary burning. It is fragmentary, partly broken on the wide end. 